\title{
Trade, Education,
}

\section{and Income Inequality}

MARKUS BRUECKNER

NGO VAN LONG

JOAQUIN VESPIGNANI 


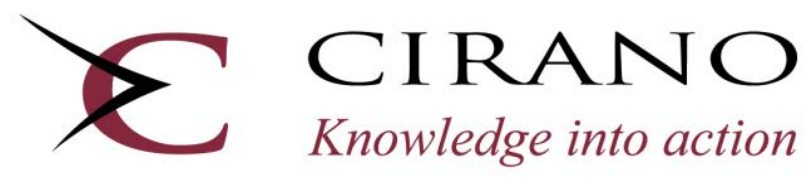

Center for Interuniversity Research and Analysis on Organizations

The purpose of the Working Papers is to disseminate the results of research conducted by CIRANO research members in order to solicit exchanges and comments. These reports are written in the style of scientific publications. The ideas and opinions expressed in these documents are solely those of the authors.

Les cahiers de la série scientifique visent à rendre accessibles les résultats des recherches effectuées par des chercheurs membres du CIRANO afin de susciter échanges et commentaires. Ces cahiers sont rédigés dans le style des publications scientifiques et n'engagent que leurs auteurs.

CIRANO is a private non-profit organization incorporated under the Quebec Companies Act. Its infrastructure and research activities are funded through fees paid by member organizations, an infrastructure grant from the government of Quebec, and grants and research mandates obtained by its research teams.

Le CIRANO est un organisme sans but lucratif constitué en vertu de la Loi des compagnies du Québec. Le financement de son infrastructure et de ses activités de recherche provient des cotisations de ses organisations-membres, d'une subvention d'infrastructure du gouvernement du Québec, de même que des subventions et mandats obtenus par ses équipes de recherche.

\section{CIRANO Partners - Les partenaires du CIRANO}

Corporate Partners - Partenaires corporatifs

Autorité des marchés financiers

Bank of Canada

Bell Canada

BMO Financial Group

Business Development Bank of Canada

Caisse de dépôt et placement du Québec

Desjardins Group

Énergir

Hydro-Québec

Innovation, Science and Economic Development Canada

Intact Financial Corporation

Manulife Canada

Ministère de l'Économie, de la Science et de l'Innovation

Ministère des finances du Québec

National Bank of Canada

Power Corporation of Canada

PSP Investments

Rio Tinto

Ville de Montréal

Academic Partners - Partenaires universitaires

Concordia University

École de technologie supérieure

École nationale d'administration publique

HEC Montréal

McGill University

National Institute for Scientific Research

Polytechnique Montréal

Université de Montréal

Université de Sherbrooke

Université du Québec

Université du Québec à Montréal

Université Laval

CIRANO collaborates with many centers and university research chairs; list available on its website. Le CIRANO collabore avec de nombreux centres et chaires de recherche universitaires dont on peut consulter la liste sur son site web.

(C) June 2020. Markus Brueckner, Ngo Van Long, Joaquin Vespignani. All rights reserved. Tous droits réservés. Short sections may be quoted without explicit permission, if full credit, including (C) notice, is given to the source. Reproduction partielle permise avec citation du document source, incluant la notice (C)

The observations and viewpoints expressed in this publication are the sole responsibility of the authors; they do not necessarily represent the positions of CIRANO or its partners. Les idées et les opinions émises dans cette publication sont sous l'unique responsabilité des auteurs et ne représentent pas nécessairement les positions du CIRANO ou de ses partenaires. 


\title{
Trade, Education, and Income Inequality
}

\author{
Markus Brueckner *, Ngo Van Long ${ }^{\dagger}$, Joaquin Vespignani
}

\begin{abstract}
This paper examines the relationship between countries' bilateral trade with the United States that is not due to gravity (non-gravity trade) and the distribution of income within countries. In countries where only a small share of the population are educated, an increase in non-gravity trade is associated with a significant increase in income inequality. As education of the population increases the correlation between non-gravity trade and income inequality becomes smaller. Non-gravity trade has no significant effect on income inequality in countries that are world leaders in education.
\end{abstract}

Keywords: Non-Gravity Trade, Inequality, Education

JEL Codes: F1, E2

\section{Résumé}

Ce document examine la relation entre le commerce bilatéral des pays avec les États-Unis qui n'est pas due à la gravité (commerce non gravitaire) et la répartition des revenus au sein des pays. Dans les pays où seule une petite partie de la population est éduquée, une augmentation du commerce non gravitaire est associée à une augmentation significative des inégalités de revenus. À mesure que l'éducation de la population augmente, la corrélation entre le commerce non gravitaire et l'inégalité des revenus diminue. Le commerce non gravitaire n'a pas d'effet significatif sur l'inégalité des revenus dans les pays qui sont les leaders mondiaux de l'éducation.

Mots-clés : Commerce non gravitaire, Inégalité, Éducation

Codes JEL : F1, E2

\footnotetext{
${ }^{*}$ Research School of Economics, Australian National University; Tel: +61 2 61253881; Email address: markus.brueckner@anu.edu.au

${ }^{\dagger}$ Department of Economics, McGill University and CIRANO; Tel: 1-514 3984400 (extension 00309) Mail address: ngo.long@mcgill.ca

\#niversity of Tasmania, Tasmanian School of Business and Economics, Australia; Tel.

No: +61 3 62262802; E-mail address: Joaquin.Vespignani@utas.edu.au
} 


\section{Introduction}

Non-gravity trade is the exchange of goods and services that is not determined by standard variables entering a gravity equation, most importantly, following Tinbergen (1962), distance between countries and their economic mass. In the spirit of this definition we construct measures of bilateral non-gravity trade between the United States and 154 countries. An interesting stylized fact is that non-gravity trade displays much more volatility than gravity trade: The within-country variance of non-gravity trade is about one order of magnitude larger than the within-country variance of gravity trade. Table 1 shows that this stylized fact is robust to a variety of specifications of the gravity equation; splitting the time period into pre- and post1990; and separating countries into low, middle, and high income as defined by the World Bank.

Our contribution to the trade literature is threefold. First, we introduce the concept of nongravity trade. Analogous to the literature on total factor productivity, non-gravity trade is computed as a residual. Our second contribution is to show that the distinction between gravity trade and non-gravity trade matters. We demonstrate that this distinction matters for a particular outcome: income inequality. Third, we link the literature on international trade and income distribution with the literature on education and labor mobility. We show that education has a significant effect on the relationship between non-gravity trade and income inequality.

Our econometric model relates income inequality to trade, education, and the interaction between trade and education. The estimates of the model show that in countries where only a small share of the population are educated, an increase in non-gravity trade is associated with a significant increase in income inequality. As education of the population increases the positive correlation between non-gravity trade and income inequality becomes smaller. There is no significant relationship between non-gravity trade and income inequality in countries that are at the frontier of education.

We consider both quantity and quality measures of education. The quantity of education is measured by the share of the population with primary schooling. The quality of education is measured by the average of pupils' PISA tests scores. The estimated model shows that both quantity and quality of education matter for the relationship between non-gravity trade and income inequality. Conditional on the quality of education, a larger share of the population 
with primary schooling significantly attenuates towards zero the positive relationship between non-gravity trade and income inequality. The same holds for the quality of education: Conditional on the quantity of education, higher average test scores significantly attenuate towards zero the positive relationship between non-gravity trade and income inequality.

An explanation for why education affects the relationship between non-gravity trade and income inequality is that: (i) trade openness affects the relative value marginal product of labor between the tradable and non-tradable sector; and (ii) education improves workers' ability to switch between sectors, i.e. it increases inter-sectoral labor mobility. An increase in trade openness increases the wage in the tradable sector relative to the wage in the non-tradable sector - and more so the less mobile is labor between the tradable and the non-tradable sector. In the extreme case of perfect labor mobility, international trade has no effect on the relative wage. To understand why that is the case, note that an increase in trade openness increases the value marginal product of labor in the tradable sector (relative to the value marginal product of labor in the non-tradable sector). There is an increase in the demand for labor in the tradable sector; whether this has a large or small effect on the wage paid in that sector depends on the elasticity of labor supply. If firms operating in the tradable sector can easily fill vacant positions with workers that were previously employed in the non-tradable sector, then the effect of an increase in trade openness on the relative wage between the tradable and non-tradable sector is small. $^{1}$

${ }^{1}$ In the appendix we make the argument formally in an open economy model. In this footnote we sketch the main idea for an economy with a tradable good, $\mathrm{Y}^{\mathrm{T}}$, and a non-tradable good, $\mathrm{Y}^{\mathrm{NT}}$. In this economy perfect competition equates the wage, $\mathrm{W}$, to the value marginal product of labor, $d(P Y) / d L$. Consider now two extremes: (i) labor is sector-specific, i.e. labor is immobile between the tradable and non-tradable sector; (ii) labor is perfectly mobile across sectors. In the first case it holds that:

(i) $\mathrm{W}^{\mathrm{T}} / \mathrm{W}^{\mathrm{NT}}=\left[\mathrm{d}\left(\mathrm{P}^{\mathrm{T}} \mathrm{Y}^{\mathrm{T}}\right) / \mathrm{dL}^{\mathrm{T}}\right] /\left[\mathrm{d}\left(\mathrm{P}^{\mathrm{NT}} \mathrm{Y}^{\mathrm{NT}}\right) / \mathrm{dL}^{\mathrm{NT}}\right]$

An increase in trade openness -- $\mathrm{P}^{\mathrm{T}} \mathrm{Y}^{\mathrm{T}} /\left(\mathrm{P}^{\mathrm{NT}} \mathrm{Y}^{\mathrm{NT}}+\mathrm{P}^{\mathrm{T}} \mathrm{Y}^{\mathrm{T}}\right)$-- increases the right-hand side of the above equation. (For the Cobb Douglas production function, the right-hand side is $\left[\mathrm{P}^{\mathrm{T}} \mathrm{Y}^{\mathrm{T}} / \mathrm{P}^{\mathrm{NT}} \mathrm{Y}^{\mathrm{NT}}\right]^{*}\left[\mathrm{~L}^{\mathrm{NT}} / \mathrm{L}^{\mathrm{T}}\right]$ ). Hence, an increase in trade openness increases inequality (under the standard assumption that productivity in the tradable sector is higher than in the non-tradable 
There is an important difference between gravity and non-gravity trade with regard to the impact of these variables on income inequality. The effect of trade that is due to gravity forces, i.e. gravity trade, is statistically insignificant and quantitatively small. Regardless of education, there is no significant effect of gravity trade on income inequality.

We use instrumental variables methods to corroborate that our empirical results are causal. Our instrument for non-gravity trade is the average US import tariff on manufacturing goods produced by country $i$ in year $t$. Given that the US is by far the largest economy in the world, this instrument is plausibly exogenous for almost all countries in the world. (A handful of not so small economies vis-à-vis the US, i.e. China, Japan, Germany, and the United Kingdom, can be excluded from the sample, and we do that as a robustness check.) First stage regressions show that the higher the import tariff imposed by the US on country $i$ the lower is country $i$ 's non-gravity trade vis-à-vis the US. In the second stage we find that, on average, there is a significant positive relationship between non-gravity trade and income inequality.

One way to think of non-gravity trade is that it induces unexpected changes in the value marginal product of labor in the tradable sector. Education improves workers' ability to adjust to those unexpected changes in the relative demand for labor between the tradable and nontradable sector. This may be because better educated workers can more quickly learn new tasks; or, because, better educated workers have lower search costs. In contrast, if people know from the beginning how trade affects relative labor demand between the tradable and non-tradable sector, then they can plan in advance. Gravity trade is long-run trade. And in the long-run, labor is perfectly mobile between the tradable and non-tradable sector. That is why gravity trade has no effect on the within-country income distribution.

The rest of the paper is organized as follows. Section 2 relates the paper to the literature. Section 3 discusses estimates of the gravity equation; this section clarifies how we compute non-gravity trade. Section 4 presents estimates of the average relationship between non-gravity trade and

sector). In the other extreme case of perfect labor mobility across sectors, perfect competition forces the wages to equalize:

(ii) $\mathrm{W}^{\mathrm{T}}=\mathrm{W}^{\mathrm{NT}}$

From equation (ii) it follows that trade openness has no effect on income inequality. 
inequality. Section 5 shows estimates of the effect that education has on the relationship between non-gravity trade and inequality. Robustness checks are discussed in Section 6 . Section 7 concludes.

\section{Section 2. Related Literature}

Our paper is related to three strands of literature: (i) The gravity models, (ii) the relationship between openness and inequality, and (iii) the role of education on labor mobility. In this section, we offer a brief review of each of these strands of literature.

\subsection{The gravity model}

Tinbergen (1962) found a striking empirical relationship: the trade flows between any two countries are proportional to their gross national products and inversely proportional to the distance between them. He wrote that "the purpose of this econometric exercise is to find out which countries show substantial negative deviations, for these would be indicative of the existence of special barriers and obstacles to the optimal flow of international trade"' (p. 262).

Tinbergen's formulation was of the following form: the log of exports of country I to country $\mathrm{j}$ is equal to a constant plus the alpha times the log of the GNP of country $\mathrm{i}$, plus beta times the $\log$ of the GNP of country $\mathrm{j}$ minus gamma times the log of distance between the two countries. The estimate for gamma was closed to unity.

In a final exercise, Tinbergen included additional explanatory variables, such as special trade agreements. Thus, there was a dummy variable for the British Commonwealth preference. The Benelux preference was represented by another dummy variable. A third dummy variable takes the value of 1 for adjacent or neighbouring countries and zero otherwise.

Tinbergen's regression equation became known as the gravity equation, as it has some resemblance to the Newtonian theory of gravitational attraction, in which the mass of two objects and the distance between them are the fundamental variables. (In physics, the value for gamma is 2, while in economics, most estimates for gamma hover around 1). Since the publication of Tinbergen's work, thousands of regressions of this type have been performed using different data sets and under different formulations of the concept of distance. Distance, 
in a generalized sense, can include a variety of factors that create resistances to trade flows. Proxies for frictions such as bilateral distance are used along with measures such as past colonial relationship (Head et al., 2010), common language, free trade agreements, monetary union (Rose, 2000; Rose and van Wincoop, 2001), and network structure (Rauch and Trindale, 2002; Combes et al. 2005; Chaney, 2014). Generally speaking, most empirical estimates tend to confirm a gravity type relationship.

In a meta-analysis, Head and Mayer (2014) reviewed 1,835 estimates of the distance coefficient in 161 articles. Of these estimates, 328 are structural in the sense that they include fixed effects for importing/exporting countries, or a use a ratio-type method. The average of structural estimates for gamma is 1.1 , and the average of non-structural estimates is 0.9 .

A most striking empirical study using the gravity equation was that of McCallum (1995). According to McCallum's finding, a major resistance to trade flow is national borders. Using 1988 data, McCallum's gravity equation, which includes a dummy variable representing national border, results in a surprising finding that, other things being equal, trade between two Canadian provinces is 22 times greater than trade between a Canadian province and a US state. This estimate has been described as one of the six major puzzles in international macroeconomics (Obstfeld and Rogoff, 2001). Numerous authors re-examined McCallum's results, but found no major objection, until 8 years later, when Anderson and van Wincoop (2003) argued that the gravity equation, as used in McCallum, lacks a theoretical foundation. They then develop a simple model of trade that gives rise to a theoretically well-founded gravity equation. Their theory implies that McCallum's regression equation involved the omission of important multilateral trade resistance variables that are correlated with McCallum's variables on the right-hand side. As is well known, omitted variables can mean that the estimated coefficients of the regression are biased.

The theoretical foundation provided by Anderson and van Wincoop is based on the earlier paper by Anderson (1971), where it is assumed that goods produced by different regions are regarded by consumers as different goods and consumers have a CES preference structure. This means that each country's import demand functions for each good depend on its theoretical price index which reflects the barriers of trade on all goods that a country imports from the rest of the world. These theoretical price indices are called the multilateral resistances. These variables are omitted in McCallum's regression equation. Anderson and van Wincoop 
emphasize that the theoretical price indices are not observable variables: they are not the same as the price indices constructed by national statistical offices.

Taking into account the multilateral resistance terms, Anderson and van Wincoop find that Canadian provinces trade 10.7 times more with themselves than with the US states (a substantial difference from McCallum's number, 22), whereas US states trade 2.24 times more among themselves than with Canadian provinces. This reflects the fact that Canada, being a small open economy, imports a wider range of goods than the US does.

While Anderson and van Wincoop (2002) assume perfect competition, it is also possible to provide a theoretical foundation for the gravity equation by assuming monopolistic competition, as in Bergstrand $(1985,1989)$. Deardorff (1998) showed that the gravity equation can also be derived under the Heckscher-Ohlin structure. A multisector endowment model of gravity trade is developed by Anderson and Yotov (2016).

Eaton and Kortum (2002) derived a gravity equation using a general equilibrium model of trade under perfect competition. They assume the Ricardian technology with a continuum of goods, in which countries draw labor productivities from a Frechet probability distribution. In equilibrium, each country specializes in a range of sectors. Countries differ in terms of absolute advantages as well as comparative advantages. Changes in trade costs have impact on wage rates and national incomes.

The Eaton-Kortum model has been generalized by Costinot et al. (2012) to a multisector Ricardian model. This work has been applied to the analysis of NAFTA (Caliendo and Parro, 2015).

Chaney (2008) offers a different theoretical derivation of the gravity equation, where fixed costs of exports and firm heterogeneity play an important role. His model is an extension of Melitz (2003) in that the world consists of many asymmetric countries, separated by asymmetric trade barriers. As in Helpman, Melitz and Yeaple (2004), Chaney (2008) assumes that productivity shocks are drawn from a Pareto distribution. Unlike Melitz (2003), Chaney (2008) does not impose free entry. Instead he assumes that the total mass of potential entrants in any given country is proportional to its size. He finds that the resulting gravity equation contains both variable trade costs and fixed trade costs. A country's export volume is shown to increase in its labor productivity as well as its size. The impact of trade barriers (which increase both fixed cost and variable cost) is decomposed in two margins: the intensive margin, and the 
extensive one. The intensive margin refers to changes in the volume of export of an existing exporting firm, whereas the extensive margin refers the contribution to exports by new entrants to the industry.

Until recently, there has been no explanation as to why most estimates of elasticity of trade with respect to an increase in distance are around 1. In an innovative paper, Chaney (2018) derives a set of three conditions that, taken together, is sufficient to generate the elasticity of unity. These conditions are: (i) firm sizes follow a Pareto distribution, (ii) the average squared distance of exports is an increasing power function of firm size, and (iii) a parameter restriction holds.

\subsection{Openness and inequality}

There has been a great deal of empirical studies on the relationship between globalization and inequality (e.g., Feenstra and Hanson, 1996, 1997, 1999, 2003; Goldberg and Pavcnik, 2007; Gozgor and Ranjan, 2017; Dorn, Fuest, and Potrafke, 2018).

Goldberg and Pavcnik (2007) provided a comprehensive review of the evidence of this relationship for developing economies. They found that the evidence suggests a "contemporaneous increase in globalization and in inequality in most developing countries. However, establishing a causal link between these two trends has proven more challenging."

Dorn, Fuest, and Potrafke (2018) found that there is a significant positive relationship between globalization and inequality in the transition economies including China and most countries of Middle and Eastern Europe. However, they report that in the sample of the most advanced economies, neither OLS nor 2SLS results show any significant positive relationship between globalization and inequality, even though both globalization and income inequality in these countries slightly increased in the 1990s (p. 12). Dorn and Schinke (2018) found that globalization increased the income shares of the rich in Anglo-Saxon countries, but not in other OECD countries. Dorn, Fuest, and Potrafke (2018) suggested that institutions such as the transfer system and opportunities for education might play a moderating role.

Measures of inequality used in the above studies include skill premium, Gini of log wages, gross income Gini and net income Gini. Globalization measures include average tariffs, average non-tariff barriers, and KOF index of globalization (Dreher, 2006; Dreher et al., 2008). 
Even though Dorn et al. (2018) find that there is no significant relationship between globalization and income inequality in advanced economies, some earlier empirical studies (e.g. Wood, 1995; Leamer, 1998) have documented a tendency for increased wage inequality in the USA. Some authors have observed that the impact of trade liberalization on wages may depend on the level of aggregation of worker types. As documented in Autor and Dorn (2013), in the USA the wage profile has experienced substantial changes. Wages of highly skilled workers have risen, and so have wages of very low-skilled workers, whereas the wages of workers in the middle range of skill have declined. While Autor and Dorn (2013) attributed these developments to technological change, in their later works with Hanson (Autor, Dorn and Hanson, 2013, 2015) they also referred to the impact of trade with China.

What does trade theory predict about the effect of trade liberalization on wage inequality? The earlier studies rely on the Heckscher-Ohlin (H-O) theory, which focuses on sectoral reallocation of factors of production (see Wood,1995; Leamer 1998; and for an overview, Wood, 1999). For example, in a H-O model where skilled labor and unskilled labor are the two primary factors of production, following multilateral reduction in trade barriers, countries that are relatively abundant in skilled labor will be able to expand their exports of the skill-intensive goods, and consequently their skill workers will experience an increase in skill premium. A problem with this explanation of rising skill premium in the USA is that the same model would predict a falling skill premium in countries that are relatively abundant in unskilled labor, a prediction which would not be supported by facts (for example, Feenstra and Hanson (1997) found that skill premium also rose in Mexico).

Many international trade economists have therefore departed from the $\mathrm{H}-\mathrm{O}$ model, by taking account of vertical production structure, in which production and offshoring of intermediate goods or services play an important role (Feenstra and Hanson, 1996, 1997, 1999, 2003; Antras and Helpman, 2004; Grossman and Rossi-Hansberg, 2008). Thus, while the US firms keep the skill-intensive activities at home, their offshored activities along the value chain may be relatively skilled intensive from the perspective of the developing counties. Also, according to Feenstra and Hanson (1997), trade liberalization facilitates foreign direct investment (FDI) from advanced economies to developing countries, which increase the demand for skilled labor in the recipient countries, due to capital-skill complementarities in the developing world.

An alternative explanation for the increased demand for skilled labor is skill-biased technological change. New labor-saving technologies have indeed been responsible for 
elimination of low-skilled jobs (Berman et al. 1994, 1998; Acemoglu, 1998, 2002, Krusell et al., 2000, Card and DiNardo, 2002). However, the adoption of new skill-bias technologies could itself be influenced by the increase in trade openness. Exposure to import competition may lead local import-competing firms of developing economies to switch to more skilled intensive techniques, raising the skill premium (Cragg and Epelbaum, 1996; Bloom et al. 2016).

Another explanation for increased wage inequality relies on the heterogeneity of firms. Firms that are more productive can afford to incur the fixed costs of entering the export markets. These firms are able to pay higher wages and hire higher-skilled labor (Manasse and Turrini, 2001; Yeaple, 2005; Munch and Skaksen, 2008, Verhoogen, 2008; Egger and Kreickemeier, 2009; Egger et al., 2013). Helpman et al. (2010) introduce search and matching frictions into the model of firm heterogeneity. In their models, a worker's ability is not directly observable by the employer. Firms have an incentive to screen workers. Larger (more productive) firms have higher returns to screening, so they screen more intensively. Thus, their workforces have higher average ability. Search frictions induce multilateral bargaining between a firm and its workers. The opening of a closed economy to trade increase the dispersion of firm revenues, which in turn increases the dispersion of wages. Their main theoretical finding is that wage inequality is higher in a trade equilibrium than in autarky, but gradual trade liberalization first increases and later decreases inequality. In a follow-up paper, Helpman et al. (2017) brought the theory to the data, using a Brazilian data set for 1986-98, and found that there are sizable effects of trade on wage inequality through the mechanism of firm selection into export markets.

\subsection{Education and labor mobility}

Standard trade models (such as the Ricardian model, the Heckscher-Olin model, and the specific factor model) postulate that labor is perfectly mobile across sectors. In the real world, however, it is widely acknowledged that labor mobility across sectors or regions is very limited in the short run. There is a presumption that, when losing a job, or confronted with the prospect of a fall in their real wages, more educated workers are more likely to search and find jobs in another sector and/or regions (McCormick, 1997). There is also well documented evidence that that there is a positive correlation between earnings and years of schooling (Card, 1999). 
Establishing a causal relationship between education and mobility can be problematic. As Machin et al. (2012) put it, "even though education is connected to mobility, we do not know whether it is because of a selection of people or due to the effect of education per se', (p. 418).

There are a few empirical studies on the causal relationship between education and mobility.

McCormick (1997) documents the low rate of inter-regional migration of manual workers in the UK and finds little sensitivity of out-migration to regional labor market slack. He notes that labor mobility is greater in the US than in the UK and draws attention to the facts that the transatlantic difference in the years of schooling for manual workers is fairly large.

Using three decades of U.S. Census data, Wozniak (2010) finds that college-educated workers are much more geographically mobile than their less-educated peers: better entry labor market conditions in a state disproportionately attract college educated workers. The correlation between education and inter-regional migration has also been reported by Greenwood (1975, 1997). Malamud and Wozniak (2012) argue that there is a causal relationship behind this correlation, by exploiting variation in college attainment due to draft avoidance behavior during the Vietnam War. Machin et al. (2012) reported that the US labor mobility rate is higher than the European one, and their compulsory schooling period is also longer than in most European countries. In their empirical work, they studied an educational reform in Norway that increased the years of compulsory schooling by two years. They found a significant positive effect of education on mobility. They estimated that a year of schooling increases the regional rate of mobility by about $15 \%$ (p. 435). This effect works through channels such as having more information or having obtained skills useful in the national labor market (p. 346).

Sicherman and Galor (1990) developed a theory of career mobility. They argue that skills are to a large extent occupation specific, and education facilitates the movements across several activities. More education leads to improved probability of occupational upgrading and mobility across firms and sectors.

\section{Estimation of the Gravity Model and Non-Gravity Trade}

This section discusses estimation of a gravity model for bilateral trade. Non-gravity trade is the residual of the estimated gravity model. Following Head et al. (2010) our baseline gravity model is: 


$$
\begin{aligned}
& \log \left(\frac{\text { Bilateral Trade }_{\text {GDP }}}{i t}=\beta_{0}+\alpha \log \left(\text { Population }_{i t}\right)+\gamma \log \left(\text { Distance }_{i}\right)+\right. \\
& \delta \log \left(\text { Area }_{i}\right)+\theta \text { Border }_{i}+\varphi \text { Locked }_{i}+\text { _Language }_{i}+\rho \text { Colonial }_{i}+ \\
& \text { 'Freetrade }_{i t}+\epsilon
\end{aligned}
$$

where $\log (\text { Bilateral Trade/GDP })_{\text {it }}$ is the ratio of exports plus imports between country $i$ and the United States, divided by nominal GDP of country $i$. Population ${ }_{\mathrm{it}}$ is the country's population. Distance ${ }_{\mathrm{i}}$ is the distance of country $i$ to the US (measured in kilometres). Area $\mathrm{i}_{\mathrm{i}}$ the country's area (measured in square kilometres). Border ${ }_{i}$ is a dummy for countries that share a border with the US. Locked ${ }_{i}$ is a dummy variable for landlocked countries. Colonial ${ }_{i}$ is a dummy variable for ex-British colonies. Freetrade ${ }_{i t}$ is a dummy variable for countries with free trade agreement with the US. The coefficients $\beta_{0}, \alpha, \gamma, \delta, \theta, \varphi, \tau, \rho, \omega$ are parameters to be estimated and $\epsilon$ is an error term. Data description and sources for all variables can be found in Appendix Tables A1 to A4.

Appendix Table B1 presents estimates of the baseline gravity model. Results are similar to those obtained by Head et al. (2010). The coefficient on the log of population is positive and has an elasticity close to unity. The negative coefficient on distance indicates that geographical distance between countries reduces bilateral trade; the estimated elasticity is around -1.61 . The negative coefficient on the log of area means that larger countries trade less across borders. The coefficient on the border dummy indicates that countries with shared borders with the US (Canada and Mexico) is not statistically significant at conventional levels. Countries with open sea access (dummy $=0$ ) double their bilateral trade with the US relative to land locked countries (dummy=1). Countries in which English is the official language trade on average $73 \%$ more with the US relative to countries in which the official language is not English. The coefficient associated with colonial trade ties is statistically insignificant; this is in line with Head et al (2010)'s view that colonial trade ties have eroded after World War II. The positive coefficient on the dummy variable for free trade agreement indicates that on average countries with enforced free trade agreement with the US have much higher bilateral trade with the US, by a factor of 1.04, relative to countries without free trade agreement with the US.

\section{Non-Gravity Trade and Inequality}


Table 2 reports two-stage least squares estimates of the average effect that non-gravity trade has on income inequality. The instrument for non-gravity trade of country $i$ in year $t$ is the average import tariff that the United States imposes on manufactured goods from country $i$ in year $t$. The data are from the World Integrated Trade Solution database. The estimates reported in Table 2 are based on an unbalanced panel of 60 countries during 1981-2013; this is the largest sample given the available data.

Column (1) of Table 2 shows results when the dependent variable is the Gini. One can see that the estimated coefficient on non-gravity trade is positive and significantly different from zero at the 1 percent significance level. Quantitatively, the coefficient in column (1) can be interpreted as follows: a one standard deviation increase in non-gravity trade increases the Gini coefficient by about 6 percentage points on average.

Non-gravity trade increases the income shares of the rich and reduces the income shares of the poor. This can be seen from columns (2)-(5) of Table 2 where the dependent variables are the income shares of the top $10^{\text {th }}$, top $20^{\text {th }}$, bottom $20^{\text {th }}$ and bottom $10^{\text {th }}$ percentile, respectively. From columns (2) and (3) of Table 2 one can see that the estimated coefficient on non-gravity trade is significantly positive. Non-gravity trade significantly increases the income shares of the richest $10^{\text {th }}$ and $20^{\text {th }}$ percent. A one standard deviation increase in non-gravity trade increases the income shares of the richest $10^{\text {th }}$ and $20^{\text {th }}$ percent by around 4 to 5 percentage points. Columns (4) and (5) show that the income shares of the poor decrease significantly. A one standard deviation increase in non-gravity trade decreases the income shares of the bottom $10^{\text {th }}$ and $20^{\text {th }}$ percentile by around 1 to 2 percentage points on average.

From the first stage estimates in Panel B of Table 2 one can see that the IV estimates are based on a strong instrument. In the literature the precision of the first-stage estimates is typically judged by the Cragg Donald F-statistic. This test statistic is then compared to the critical values tabulated in Stock and Yogo (2005). In Table 2 the Cragg Donald F-statistic is around 60. According to the tabulations in Stock and Yogo (2005) one can reject the null that the size distortion of the IV regressions in Table 2 is above 5 percent at the 5 percent significance level.

From Panel B of Table 2 one can see that the estimated coefficient on the US import tariff is negative and significantly different from zero at the 1 percent significance level. The negative coefficient means that the higher the US import tariff on country $i$ the smaller is country $i$ 's non-gravity bilateral trade vis-a-vis the US. This is plausible as a higher tariff on the goods of 
country $i$ means that these goods are more expensive for US consumers. Consequently, exports of country $i$ to the US decline.

Comparing the instrumental variables estimates in Panel A to the least squares estimates in Panel C, one can see that IV and LS yield the same sign on non-gravity trade. Quantitatively, the IV coefficients on non-gravity trade are larger in absolute value than the LS coefficients. Least squares estimation thus leads to an understatement of the average effect that non-gravity trade has on income inequality.

The assumption in the IV regressions is that the import tariff that the US government imposes on country $i$ is not systematically affected by income inequality in country $i$. This is plausible: US government maximizes utility of US citizens only; it does not take into account utility of citizens of other countries. US government's trade policies would only take into account inequality in country $i$ to the extent that income distribution in country $i$ has an effect on the US economy. It is unlikely that the US government's trade policies are a function of inequality in country $i$ : for just about all countries in the world, each country is economically small relative to the US economy. The US economy makes up more than one-quarter of world GDP, and this has been the case throughout the entire period of the panel dataset that we use to estimate the econometric model. The second largest economy in the world is currently China with about 15 percent of world GDP. The third, fourth, and fifth largest economies are Japan, Germany, and the United Kingdom that make up about 6, 5, and 3 percent of world GDP, respectively. In Table 3 we show that we obtain similar results if we exclude from the sample this handful of economies.

In Table 4 we add gravity trade, as predicted by equation (1), to the right-hand side of equation (2). We continue to instrument non-gravity trade of country $i$ in year $t$ by the average import tariff imposed by the US on country $i$ in year $t$. Excluded from the sample are relatively large economies, i.e. China, Japan, Germany, and the United Kingdom. One can see from column (1) of Table 4 that, on average, gravity trade has no significant effect on the Gini coefficient. The effect of non-gravity trade remains positive and significantly different from zero at the 1 percent significance level. From columns (2) and (3) of Table 4 one can see that non-gravity trade significantly increases the income shares of the top $10^{\text {th }}$ and $20^{\text {th }}$ percentiles; there is no significant effect of gravity trade on these variables. Non-gravity trade significantly reduces the income shares of bottom $10^{\text {th }}$ and $20^{\text {th }}$ percentiles. This is true for both two-stage least squares regressions (Panel A) and least squares regressions (Panel B). 
The results above are for bilateral trade vis-à-vis the United States. A natural follow-up question is what happens if one uses multilateral trade data. To answer that question, we show in Table 5 estimates when the gravity equation is estimated based on multilateral trade data. Specifically, we estimate equation (1) using bilateral trade data for all country pairs. Then we generate gravity trade of country $i$ in year $t$ as the sum of predicted trade flows across all $j$ trading partners in year $t$; non-gravity trade of country $i$ in year $t$ is the sum of the residual trade flows across all $j$ trading partners in year $t$.

From column (1) of Table 5 one can see that when using multilateral trade flows the estimated coefficient on non-gravity trade is positive and significantly different from zero at the conventional significance levels. The coefficient on gravity trade is quantitatively much smaller than the coefficient on non-gravity trade. One cannot reject the hypothesis that the coefficient on gravity trade is equal to zero at the conventional significance levels. Quantitatively, the interpretation of the coefficient on non-gravity trade in column (1) is that a one standard deviation increase in non-gravity trade increases the Gini coefficient by around 9 percentage points.

The instrument in the two-stage least squares regressions in Table 5 is the interaction between the international oil price and countries' average GDP shares of oil net exports. ${ }^{2}$ The exogeneity assumption is that inequality of a country does not affect the international oil price. This assumption is plausible for the majority of countries: most countries in the world export or import only a small fraction of total world exports and imports of oil. There are however a few countries that are large exporters and importers of oil. Panel B of Table 5 shows that the two-stage least squares estimates are robust to excluding from the sample the five largest oil importers and the five largest oil exporters.

Comparing Table 5 to Table 2, one can see that qualitatively estimates that are based on multilateral trade data are similar to estimates that are based on data of bilateral trade vis-à-vis the United States. Quantitatively, the multilateral trade data suggests a somewhat larger effect of non-gravity trade than data that is limited to bilateral trade vis-à-vis the United States.

\footnotetext{
${ }^{2}$ For the multilateral trade data we cannot use tariffs as an instrument for non-gravity trade. This is because the exogeneity assumption is not plausible for all countries; only for a large economy like the US is the assumption that a tariff imposed by the US on manufacturing products of country $i$ is exogenous to inequality of country $i$.
} 


\section{The Role of Education}

The econometric model that we use to estimate how the effect of non-gravity trade on inequality depends on education is:

$$
\begin{aligned}
& \text { Gini }_{i t}=\beta_{0}+\pi \text { Non }- \text { Gravity Trade }_{i t}+\omega \text { Quality of Education }_{i}+ \\
& \lambda \text { Quantity of Education }_{i}+\text { vNon }- \text { Gravity Trade }_{i t} * \text { Quality of Education }_{i}+\chi \text { Non }- \\
& \text { Gravity Trade }_{i t} * \text { Quantity of Education }_{i}+\varepsilon
\end{aligned}
$$

Quality of Education $_{\mathrm{i}}$ is from Hanushek and Woessmann (2009). We consider for different measures: Cognitive skills (our baseline), lower secondary education, basic education and top education. Quantity of Education $\mathbf{~}_{\mathbf{i}}$ is the inter-temporal mean of the adjusted enrolment rate of primary schooling. We use the inter-temporal mean due to sparsity of time-varying data, in particular, for the quality of education.

Table 6 presents least squares estimates of the econometric model specified in equation 2 . The $\mathrm{R}^{2}$ of the estimated model is around 0.5 ; this means that up to half of the variation in inequality can be explained in the baseline model by non-gravity trade, education, and the interaction between non-gravity trade and education.

In the first row of column (1) of Table 6 the estimated coefficient on non-gravity trade is reported. This coefficient is positive and significantly different from zero at the $1 \%$ level. From the second and third row of Table 6 one can see that both the quantity and quality of education are negatively related to inequality. The coefficient on the interaction term between non-gravity trade and quality of education is negative and significantly different from zero at the 1 percent level and so is the coefficient on the interaction between non-gravity trade and the quantity of education.

Column (2) of Table 6 shows that -- regardless of education -- there is no significant relationship between gravity trade and inequality. The coefficient on gravity trade is not significantly different from zero at the conventional significance levels. The coefficient on the interaction with quantity of education is also statistically indistinguishable from zero at the conventional significance levels. The coefficient on the interaction between gravity trade and the quality of education is negative and significantly different from zero at the 1 percent 
significance level. However, across all sample values of the quantity of education the effect of gravity trade on the Gini are not significantly different from zero.

To facilitate interpretation of the estimates reported in Table 6 it is useful to differentiate equation (2) with respect to non-gravity trade:

$$
\left.\frac{\text { dGini }}{\text { dNon-GravityTrade }}=26.35-3.10 \text { (Quality of Educ.) }-0.11 \text { (Quantity of Educ. }\right)
$$

Where equation (3) uses the estimated coefficient in column (1) of Table 6. From the above equation one can see that the effect of non-gravity trade on the Gini is a decreasing function of education.

Based on equation (3) and plugging in the data on the quality and quantity of education, we compute for each country in the sample the effect of non-gravity trade on the Gini. Table 7 lists these effects. For countries that are at the lower end of the distribution of education, non-gravity trade has a large positive effect on the Gini that is significantly different from zero at the 5 percent level or higher. Consider, for example, countries such as Morocco, Ghana, and Peru: in these countries a one standard deviation increase in non-gravity trade is associated with an increase in the Gini coefficient of around 10 percentage points. For the median country the relationship between non-gravity trade is still positive and significantly different from zero at the 5 percent level. But quantitatively the effect is much smaller: at sample median, a one standard deviation increase in non-gravity trade is associated with an increase in the Gini coefficient of around 1 to 2 percentage points. For countries with relatively high values of education there is no significant relationship between non-gravity trade and income inequality.

Figures 1a (1b) plot the marginal effects, $\frac{\partial \text { Gini }}{\partial \text { Non-Gravity Trade }}$ on the y-axis, against sample values of the quality (quantity) of education, on the x-axis. In Figure 1a the marginal effect is plotted for different values of the quality of education (setting quantity of education at the mean value). One can see that at the sample minimum of the quality of education the marginal effect is around 7 while at sample maximum it is around 0 . In Figure $1 \mathrm{~b}$ the marginal effect is plotted for different values of the quantity of education (setting quality of education at the mean value). One can see that at the sample minimum of the quantity of education, the marginal effect is around 11 while at sample maximum it is around 0 . Thus, differences in the quantity of 
education have a larger impact on the effect that non-gravity trade has on income inequality than differences in the quality of education.

World leaders have recognized the importance of increasing education in developing countries (see e.g. Hillman and Junker, 2004). Throughout the past two decades, low income countries made significant progress in terms of increasing the share of the population with primary schooling: in the 1980s and early 1990s the average enrolment rate in primary school was below $50 \%$; by the 2010 s it was nearly $80 \%$. Based on equation (3), Figure 2 shows that a one unit increase in non-gravity trade was associated in low income countries with an about 9 percentage points increase in the Gini coefficient during the 1980s. By the 2010s this effect was below 6 percentage points. For comparison, in the group of middle (high) income countries the effect was around 4 (0) percentage points during the 1980s and below 3 (0) percentage points by the 2010s. The significant progress in primary school enrolment in low income countries thus contributed to a substantial decrease in the impact that non-gravity trade had on income inequality in this group of countries.

It is noteworthy that according to Table 6 education is associated with significantly less income inequality (and more so in countries with greater non-gravity trade). The coefficient on the quality of education is around -11.25 ; for quantity of education it is -0.11 . Both coefficients are significantly different from zero at the conventional significance levels. Quantitatively, the effect that education has on income inequality is sizable. For example, when non-gravity trade is set equal to zero, a 1 standard deviation increase in the quality of education is associated with a decline in the Gini of around 6 percentage points; a 1 standard deviation increase in the quantity of education is associated with a decline in the Gini of around 2 percentage points.

\section{Mechanism: Relative Wage Between Tradable and Non-tradable Sector}

We now present evidence consistent with the mechanism sketched in the introduction: education mediates the effect that non-gravity trade has on the relative wage between the tradable and non-tradable sector. In countries where only a small share of the population are educated, non-gravity trade increases the wage ratio of the tradable to non-tradable sector; there is no effect of gravity trade on the relative wage between the tradable and non-tradable sector. 
In Table 8 the dependent variable is the log of the ratio of the wage in the manufacturing sector (tradable) over the wage in the construction sector (non-tradable). One can see that the coefficient non-gravity trade is significantly positive while the coefficient on gravity trade is insignificant and quantitatively small. The coefficient on non-gravity trade is about 7 times the coefficient on gravity trade. The coefficients on the interaction between non-gravity trade and education are significantly negative. The interpretation is that education significantly reduces the effect that non-gravity trade has on the relative wage between the tradable and non-tradable sector. So much so, that in countries that are in the top $75^{\text {th }}$ percentile of education, non-gravity trade has no significant effect on the ratio of the tradable-to-nontradable wage.

\section{Robustness}

\subsection{Alternative Measures of the Quality of Education}

Table 9 shows estimates for alternative measures of the quality of education. The alternative measures of the quality of education are from Hanushek and Woessman. The variables are lower secondary, basic education and top education (see the Appendix). The estimated coefficients on the interactions with non-gravity grade are negative and significantly different from zero at the 1 percent level for all three measures of the quality of education. Noteworthy is that the coefficient on the interaction between non-gravity trade and top education is particularly large. Top education has a larger effect on the impact that non-gravity trade has on inequality than basic education and lower secondary.

\subsection{Alternative Measures of Income Inequality}

In Table 10 we report estimates of models where the dependent variables are the shares of income of the poorest $10 \%, 20 \%$, and the richest $20 \%$ and $10 \%$, respectively. ${ }^{3}$ The first two measures are inverse measures of inequality: a higher share of income going to the poorest $10 \%$ or $20 \%$ means that income inequality decreases. By contrast, an increase in the share of income accruing to the richest $20 \%$ or $10 \%$ means that income inequality increases. What the above measures enable to study is how non-gravity trade affects the shares of income accruing at the

\footnotetext{
${ }^{3}$ We also estimated the model with the share of income held by the poorest $10 \%$ as dependent variable. Results are similar in terms of sign, magnitude and statistical significance to those reported in Table 5. Results are not reported and are available upon request from the authors.
} 
bottom and top of the distribution. The Gini that we used as our baseline measure for income inequality is an aggregation of income shares across the entire distribution.

From columns (1) and (2) of Table 10 one can see that the estimated coefficients on non-gravity trade are significantly negative while the coefficients on the interaction between non-gravity trade and education are significantly positive. These estimates mean that non-gravity trade leads to a decrease of the income share held by the lower class in countries where only a small share of the population are educated. In countries that are world leaders in education, the income share of the lower class is not significantly affected by non-gravity trade.

Non-gravity trade significantly increases the share of income accruing to the top quintile and the top decile, on average, and this effect is decreasing in education. That is the interpretation of the estimates in columns (3) and (4) of Table 10. From columns (3) and (4) of Table 10 one can see that the coefficients on non-gravity trade are positive and significantly different from zero at the 1 percent significance level. The coefficients on the interaction between nongravity trade and education are negative.

\subsection{Alternative Time Periods}

Table 11 shows estimation results for alternative time periods. In column (1) results are shown for the full sample period 1981-2013; in columns (2)-(4) results are shown for the subsample periods 1990-2013, 2000-2013, and 2005-2013, respectively. One can see that the coefficients on the right-hand-side variables do not change substantially in terms of magnitude or statistical significance across these sub-samples. The R-squared of the various sub-samples considered ranges from 0.52 to 0.59 . It is slightly higher for the post-1990 period. This suggests that the model's explanatory power is substantial; and even more so for the post-Soviet union era.

\subsection{Additional Control Variables}

This section reports estimation results when including additional control variables. The purpose is to examine whether results are robust to including in the model variables that the literature has shown to be correlated with education and income inequality. One such variable is GDP per capita. Other variables are the capital-labor ratio, telecommunications infrastructure, and the GDP shares of the manufacturing and service sector. Table 12 shows that, when including 
these variables and their interactions with non-gravity trade, our main finding regarding the role of education remains intact.

\subsection{Continent-Specific Intercepts}

Table 13 shows estimates of models that have continent-specific intercepts. Including continent-specific intercepts marginally increases the explanatory power of the model. The Rsquared is around 0.58 to 0.60 in columns (1)-(5) of Table 12 where indicator variables are included as controls for Africa, Asia, America, Europe, and Oceana. One can see from Table 13 that including continent indicator variables in the model barely changes the estimated coefficients and standard errors on non-gravity trade, education, and the interaction between education and non-gravity trade.

6.6 Upper and Lower 95\% Confidence Interval of the Estimated Coefficients of the Baseline Gravity Model

The non-gravity trade variable is constructed as a residual from an estimated gravity equation. The coefficients in the gravity equation have standard errors; hence, one can construct a 95 percent confidence interval for each of the coefficients in the gravity equation. In this section we discuss results for two cases. The first case is a measure of non-gravity trade that is based on the top of the 95 percent confidence intervals of the coefficients in the gravity equation. The second case, which is exactly the opposite of the first, is to construct non-gravity trade based on the bottom of the 95 percent confidence intervals of the estimated coefficients in the gravity equation. Table 14 shows that the empirical findings hold for both cases.

\subsection{Bilateral Trade}

In this section we show that when the right-hand side variable is trade openness (i.e. no distinction between gravity and non-gravity trade), there is no significant relationship with inequality. Column (1) of Table 15 shows estimates of equation (2) when, instead of nongravity trade, we use the log of the ratio of bilateral trade over GDP. Column (2) adds as righthand side control variables geographic distance and the log of population size. In column (3) 
the proxy for mass is the log of GDP. In column (4) the control variables are the same as the right-hand-side variables in equation (1).

One can see from Table 15 that the coefficient on the log of the ratio of bilateral trade over GDP is not significantly different from zero at the conventional significance levels. The coefficient on the interaction with quantity of education is also statistically indistinguishable from zero at the conventional significance levels. The coefficient on the interaction between the $\log$ of trade/GDP and the quality of education is negative and significantly different from zero at the 1 percent significance level. At sample minimum of the quality of education (3.1) the effect of a one unit increase in the log of bilateral trade over GDP on the Gini is 2.6 percentage points; one cannot reject the hypothesis that this effect is equal to zero at the conventional significance levels. At sample maximum of the quality of education (5.3) this effect is 0.6 percentage points; and in this case too one cannot reject the hypothesis that the effect is equal to zero.

\subsection{Alternative Specifications of the Gravity Equation}

Table 16 shows that our finding of a significant effect of non-gravity trade and its interaction with education is robust to alternative specifications of the gravity equation. Non-gravity trade is the residual from an estimated gravity equation. What we report in Table 16 are the estimates of equation (2), i.e. the relationship between the Gini and non-gravity trade, for alternative specifications of the gravity equation. (Estimates of the alternative specifications of the gravity equation are not reported in the paper). For comparison purposes, we report estimates of equation (2) for the baseline specification of the gravity equation, i.e. the gravity equation that includes all the variables shown in equation (1).

In columns and (2) and (3) of Table 16 we report estimates when the gravity equation includes $\log$ distance and log mass only. This is the most parsimonious specification of the gravity equation. In column (2) the proxy for mass is population size; in column (3) the proxy for economic mass is GDP. One can see from column (2) and (3) that the estimated coefficients on non-gravity trade and the interaction with education are similar to column (1).

In columns (4) to (6) we report estimates when enriching our baseline gravity model. In column (4) we add to our baseline gravity equation a dummy variable that is unity for countries that use US dollars as an official currency. In column (5) we add a dummy variable that is unity for 
multilateral trade agreements with the US. In column (6) we add genetic distance to the US. One can see that qualitatively results are similar to column (1).

In columns (7) to (9) we report estimates when the gravity equation is specified as in Frankel and Romer (1999), Helpman et al. (2008), and Baldwin and Harrigan (2011). As one can see, our main findings hold for these alternative specifications of the gravity equation.

\subsection{Manufacturing vs. Primary Commodity Trade}

In this section we discuss results when separating trade into manufacturing and primary commodities. Table 17 shows results for manufacturing trade. Table 18 shows results for primary commodities trade. We construct non-gravity trade in the same way as before, i.e. as a residual of an estimated gravity equation. Non-gravity trade in Table 17 (18) refers to the residual of an estimated gravity equation that has as dependent variable manufacturing trade (primary commodities trade). Tables 17 and 18 are organized in the same way as Table 16 in order to facilitate comparison.

From Tables 17 and 18, one can see that the estimated coefficients on non-gravity trade are positive and significantly different from zero across all specifications. This is the case for manufacturing and for primary commodities. And there is a significant negative interaction effect for both manufacturing and primary commodities with the quantity of education. The only difference between non-gravity trade in manufacturing and primary commodities is with regard to the interaction with the quality of education. The estimated coefficients on the interaction between manufacturing non-gravity trade and the quality of education are significantly negative. There is no significant interaction with the quality of education for nongravity trade that is in primary commodities.

\subsection{Gravity Trade}

Table 19 shows that the finding of an insignificant effect of gravity trade on inequality is robust to alternative specifications of the gravity equation. To facilitate comparison to the estimated effects of non-gravity trade across different specifications of the gravity equation, Table 19 is structured in the same way as Table 16 (where we had presented estimates of the effects for non-gravity trade across different specifications of the gravity equation). In Table 19 one can 
see that across all columns the estimated coefficient on gravity trade is quantitatively small and statistically indistinguishable from zero at the conventional significance levels. The coefficient on the interaction between gravity trade and the quantity of education is also not significantly different from zero. The coefficient on the interaction between gravity trade and the quality of education is negative and significantly different from zero. However, the effects of gravity trade on inequality are not significantly different from zero across all sample values of the quality of education; and this is the case for all columns of Table 19.

\section{Conclusion}

This paper introduced the concept of non-gravity trade. Non-gravity trade differs from gravity trade. The distinction between gravity and non-gravity trade matters. For the average country in the world there exists: (i) a significant positive correlation between non-gravity trade and income inequality; (ii) an insignificant correlation between gravity trade and income inequality. These are the paper's first and second main empirical results. The third main result is that education mediates the relationship between non-gravity trade and income inequality: In countries that perform poorly along various measures of education non-gravity trade increases income inequality substantially; but in countries that are leaders in education non-gravity trade has no significant effect on income inequality. 


\section{References}

Acemoglu, D. (1998). Why do new technologies complement skills? Directed technical change and wage inequality. Quarterly Journal of Economics 113(4):1055-90.

Acemoglu, D. (2002). Technical change, inequality, and the labor market. Journal of Economic Literature 40(1): 7-72.

Anderson, J. E. (1979). A Theoretical Foundation for the Gravity Equation. American Economic Review 69(1); 106-116.

Anderson, J. E. and van Wincoop, E. (2003). Gravity with Gravitas: A Solution to the Border Puzzle. American Economic Review 93(1): 170-192.

Anderson, J. E. and Y. V. Yotov (2010). The Changing Incidence of Geography. American Economic Review 100, 2157-86.

Antràs, P. and E. Helpman (2004). Global Sourcing. Journal of Political Economy 112(3), 552580 .

Autor, D. H., and Dorn, D. (2013). The growth of low skilled service jobs and the polarization of the US labor market. American Economic Review 103(5), 1553-1597.

Autor, D. H., Dorn, D., and Hanson, G. (2013). The China Syndrome: Local labor market effects of import competition in the United States. American Economic Review 103(6), 21212168.

Autor, D. H., Dorn, D., and Hanson, G. (2015). Untangling trade and technology: Evidence from local labor markets. Economic Journal 125, 621-646.

Baldwin R. and Harrigan, J., (2011). Zeros, Quality and Space: Trade Theory and Trade Evidence. American Economic Journal: Microeconomics, 3(2). pp. 60-88.

Bergstrand, J. H. (1985). The Gravity Equation in International Trade; Some Microeconomic Foundations and Empirical Evidence. Review of Economics and Statsistics, 67(3), pp. 474-81.

Bergstrand, J. H. (1989). The Generalized Gravity Equation, Monopolistic Competition, and the Factor Proportion Theory in International Trade. Review of Economics and Statistics 71(1), 143-53.

Berman, E., J. Bound, and S. Machin (1998). Skill-biased technological change: international evidence. Quarterly Journal of Economics 113(4): 1245-79.

Berman, E., J. Bound, and Z. Griliches (1994). Changes in the demand for skilled labor within U.S. manufacturing: evidence from the annual survey of manufactures. Quarterly Journal of Economics 109(2); 367-97. 
Bloom, N., Draca, M., and van Reenen, J. (2016). Trade induced technical change? The impact of Chinese imports on innovation, IT and productivity. Review of Economic Studies 83(1): 87117.

Burstein, A., Cravino, A., Vogel, J. (2013). Importing skill-biased technology. American Economic Journal: Macroeconomics 5: 32-71.

Caliendo L. and F. Parro, (2015). Estimates of Trade and Welfare Effects of NAFTA. Review of Economic Studies 82(1): 1-44.

Card, D (1999). The causal effect of education on earnings. In Handbook of Labour Economics, Volume 3A, edited by O. Ashenfelter and D. Card. Elsevier.

Card, D., and J. DiNardo (2002) Skill biased technological change and rising wage inequality: some problems and puzzles. Journal of Labor Economics 20(4): 733-83.

Chaney, T. (2008). Distorted Gravity: The Intensive and Extensive Margins of International Trade. American Economic Review 98(4): 1707-21.

Chaney, T. (2014). The Network Structure of International Trade. American Economic Review 104(11), 3600-3634.

Chaney, T. (2018). The Gravity Equation in International Trade. Journal of Political Economy 126(1), 150-177.

Combes, P.P., Lafourcade, M., and Mayer, T. (2005). The Trade Creating Effects of Business and Social Networks: Evidence from France. Journal of International Economics 66(1): 1-29.

Costinot, A., D. Donalson and I. Komunjer (2012). What Goods do Countries Trade? A Quantitative Exploration of Ricardo's Ideas. Review of Economic Studies, 79, 581-608

Cragg, M. and Epelbaum, M. (1996). Why has wage dispersion grown in Mexico? Is it the incidence of reforms or the growing demands for skills? Journal of Development Economics, 51(1): 99-116.

Deardorff, A. 1998. Determinant of Bilateral Trade: Does Gravity Work in a Neoclassical World? In J. A. Frankel, ed. The Regionalization of the World Economy. Chicago: University of Chicago Press, pp. 7-22.

Dorn, F. and C. Schinke (2018). Top income shares in OECD countries: the role of government ideology and globalization. The World Economy 41(9): 2491-2527.

Dorn, F., Fuest, C., and Potrafke, N. (2018). Globalization and Income Inequality Revisited. Ifo Working Papers No. 247. Leibnitz Institute for Economic Research at the University of Munich.

Dreher, A. (2006). Does globalization affect growth? Empirical evidence from a new index. Applied Economics 38:1091-1110. 
Dreher, A. , N. Gaston, and P. Martens (2008). Measuring globalization: Gauging its consequences. Berlin: Springer.

Eaton, J. and S. Kortum (2002). Technology, Geography and Trade. Econometrica 70(5): 1741-1779.

Egger, H. and U. Kreickemeier (2009). Firm heterogeneity and labor market effects of trade liberalization. International Economic Review 50(1): 187-216.

Egger, H., P. Egger, and U. Kreickemeier (2013). Trade, wages, and profits. European Economic Review 64:332-350.

Feenstra, R. and Hanson, G. (1996). Foreign direct investment, outsourcing, and relative wages. In The Political Economy of Trade Policy: Papers in Honor of Jadish Bhagwati, ed. R. Feenstra, G. Grossman and D. A. Irwin, Cambridge, MIT Press, 89-127.

Feenstra, R. and Hanson, G. (1997). Foreign direct investment and relative wages: evidence from Mexico's maquiladoras. Journal of International Economics 42(34): 371-93.

Feenstra, R. and Hanson, G. (1999). The impact of outsourcing and high technology capital on wages: estimates for the United States, 1979-1990. Quarterly Journal of Economics 114(3): 90740 .

Feenstra, R. and Hanson, G. (2003). Global production sharing and rising inequality: a survey of trade and wages. In Handbook of International Trade, vol. 1, ed. E.K. Choi and J. Harrigan. Malden, Mass: Blackwell, 146-85.

Frankel, J., and Romer, D. (1999). Does Trade Cause Growth? American Economic Review, 89(3) pp. 379-99.

Goldberg, P. and Pavcnik, N. (2007). Distributional Effects of Globalization in Developing Countries. Journal of Economic Literature 45(1), 39-82.

Gozgor, C. and Ranjan, P. (2017). Globalization, Inequality, and Redistribution: Theory and Evidence. World Economy 40(12): 270-45

Greenwood, M. J. (1975). Research on internal migration in the United States: A survey. Journal of Economic Literature 13(2): 397-433.

Greenwood, M. J. (1997). Internal migration in developed countries. In Handbook of Population and Family Economics, ed. Mark R. Rosenzweig and Oded Stark. New York: Elsevier.

Grossman, G.M. and Rossi-Hansberg, E. (2008). Trade in tasks: A simple theory of offshoring. American Economic Review 98:197-897.

Hanushek, E. and L. Woessmann (2012). Do Better Schools Lead to more Growth? Cognitive skills, economic outcomes, and causation. Journal of Economic Growth, Vol. 17 (4), pp. $267-$ 321. 
Harrison, A., J. McLaren, M. McKillan (2011). Recent Perspectives on Trade and Inequality. Annual Review of Economics 3: 261-289.

Head, K. and T. Mayer. 2014. Gravity Equations: Workhorse, Toolkit and Cookbook. In Handbook of International Economics, volume 4, edited by E.H. Gita Gopinath and K. Rogoff. Amsterdam: Elsevier.

Head, K., Mayer, T., and Ries, J. (2010). The Erosion of Colonial Trade Linkages after Independence. Journal of International Economics, Vol. 81 (1), pp. 1-14.

Head, K., T. Mayer and J. Ries (2002). The Erosion of Colonial Trade Linkages after Independence. Journal of International Economics 81(1), pp 1-14.

Helpman, E., Itskhoki, O., and Redding, S. (2010). Inequality and unemployment in a global economy. Econometrica 78(4): 1239-1293.

Helpman, E., Itskhoki, O., Muendler, M.A., and Redding, S. (2017). Trade and inequality: from theory to estimation. Review of Economic Studies 84(1): 357-405.

Helpman, E., M. Melitz and Rubinstein', Y., (2008). Estimating Trade Flows: Trading Partners and Trading Volumes. Quarterly Journal of Economics, 123 (2), pp. 441-487.

Hillman, A. and E. Jenker (2004). Educating Children in Poor Countries. IMF Economic Issues, Vol 33.

Ilzetski, E., Reinhart, C. and Rogoff, K., (2010). The Country Chronologies and Background Material to Exchange Rate Arrangements into the 21st Century: Will the Anchor Currency Hold? Unpublished manuscript.

Krussel, P. L. Ohanian, L. Giovanni, J.V. RiosRull, and G. Violante (2000). Capital-skill complementarity and inequality, a macroeconomic analysis. Econometrica 68: 1029-53.

Leamer, E. (1998). In search of Stolper-Samuelson linkages between international trade and lower wages. In S. Collins, ed., Imports, Exports, and the American Worker. Washington D.C. Brookings, p. 14-1202.

Machin, Stephen, K. G. Salvanes and P. Pelkonen (2012). Education and Mobility. Journal of the European Economic Association 10(2): 41750.

Malamud, O. and A. Wozniak (2012). The impact of college graduation on migration: Evidence from the Vietnam generation. Journal of Human Resources 47(4):913-50.

Manasse, P. A. Turrini (2001). Trade, wages, and superstars. Journal of International Economics 20(2): 97-117.

McCallum, J. (1995). National Borders Matter: Canada-US Regional Trade Patterns. American Economic Review. 85(3), pp. 615-623. 
McCormick, B. (1997). Regional unemployment and labour mobility in the UK. European Economic Review 41: 581-589.

Munch, J. and R. Skaksen (2008). Human capital and wages in exporting firms. Journal of International Economics 75(2): 363372.

Novy, D. (2013). International trade without CES: Estimating Translog Gravity. Journal of International Economics, vol. 89(2), pp 271-282.

Obstfeld, M. and K. Rogoff. 2001. The Six Major Puzzles in International Macroeconomics. Is There a Common Cause? In Ben S. Bernanke and Kenneth Rogoffs (eds.), NBER macroeconomics annual 2000. Cambridge, MA. MIT Press, 2001, pp. 339-390.

Rauch, J.E. and Trindale, V. (2002). Ethnic Chinese Networks in International Trade. Review of Economics and Statistics 84(1): 116-130.

Reinhart, C., and Rogoff, K. (2004). The Modern History of Exchange Rate Arrangements: A Reinterpretation. Quarterly Journal of Economics, 119, pp. 1-48.

Rose, A. K. (2000). One Money, One Market: The Effects of Common Currency on Trade. Economic Policy 15(30): 7-46.

Rose, A. K. and E. van Wincoop (2001). National Money as a Barrier to Trade: The Real Case for Currency Union. American Economic Review 91(2): 386-90.

Sicherman, N. and O. Galor (1990). A theory of career mobility. Journal of Political Economy 98(1): 169-92.

Spolaore, E., and Wacziarg, R., (2018). Ancestry and development: new evidence.” Journal of Applied Econometrics, 33, pp 748-762.

Tinbergen, J. 1962. An analysis of world trade flows. In Shaping the World Economy: Suggestions for an International Economic Policy. New York; Twentieth Century Fund. See the book's Appendix VI, titled An Analysis of World Trade Flows, pp. 262-293.

Verhoogen, E. (2008). Trade, quality upgrading and wage inequality in the Mexican manufacturing sector. Quarterly Journal of Economics 123(2): 489-530.

Wood, A. (1995). How trade hurt unskilled workers. Journal of Economic Perspectives 9: 5780 .

Wood, A., (1999). Openness and wage inequality in developing countries: the Latin American Challenge to East Asian conventional wisdom. In Market Integration, regionalism, and the Global Economy, ed. R. Baldwin et al., Cambridge: Cambridge University Press, 153-81.

World Bank, 2016, "World Development Indicators. Available for download at http://data.worldbank.org/data-catalog/world-development-indicators 
Wozniak, Abigail (2010). Are college graduates more responsive to distant labor Market Opportunities? Journal of Human Resources 45: 944-70.

Yeaple, S. (2005). A simple model of firm heterogeneity, international trade, and wages. Journal of International Economics 65(1): 1-20. 
Figure 1. Effects of Non-Gravity Trade on Income Inequality

a.

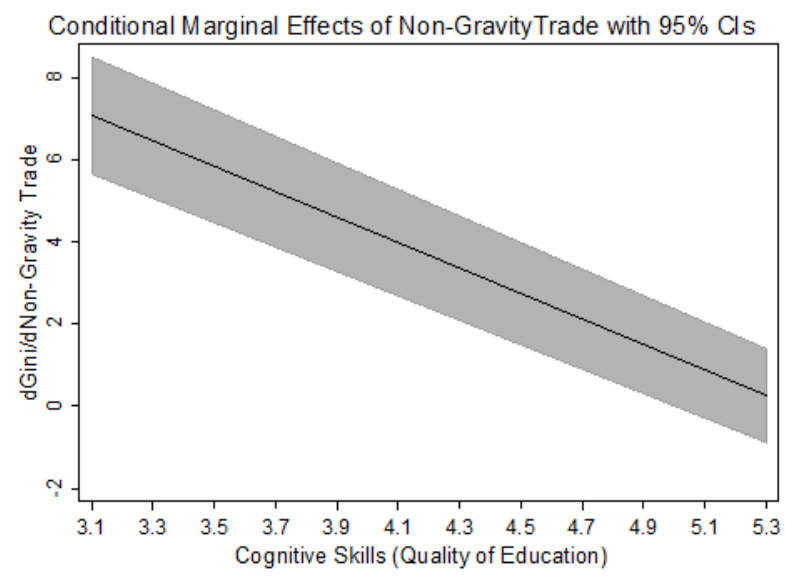

b.

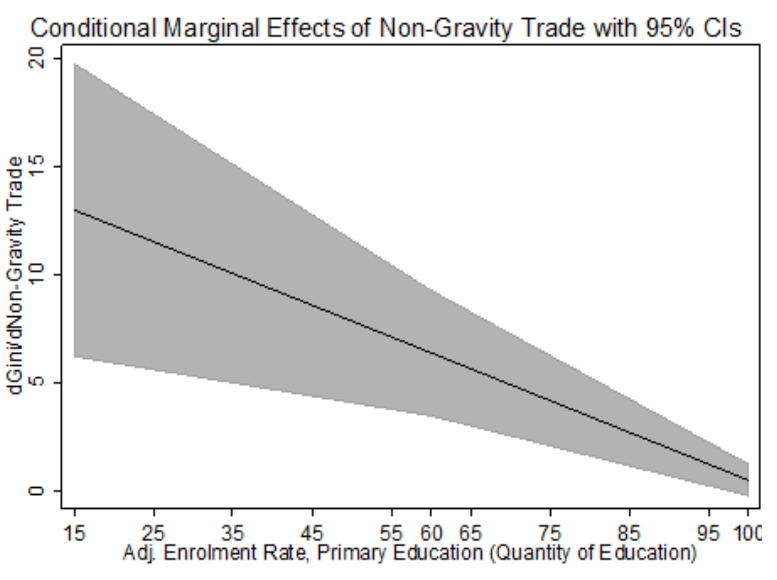

The figure is based on equation (2). Figure 1a plots the effect of non-gravity trade on the Gini (y-axis) across sample values of the quality of education (x-axis); quantity of education is set at sample mean. Figure $1 \mathrm{~b}$ plots the effect of non-gravity trade on the Gini (y-axis) across sample values of the quantity of education (x-axis); quality of education is set at sample mean. 
Figure 2: Effects of Non-Gravity Trade on Income Inequality (Low, Middle, and High-Income Countries)

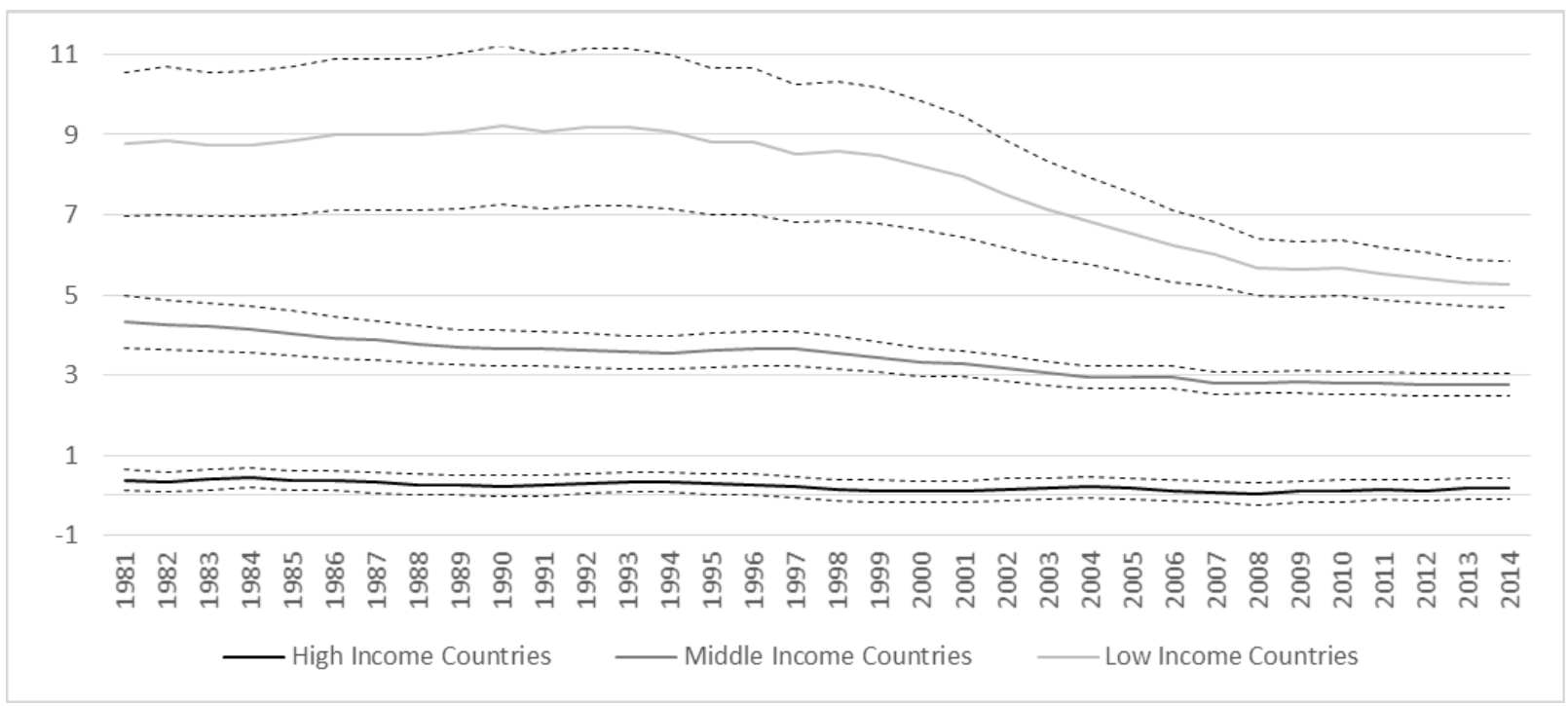

The figure shows the effect of a one unit increase in non-gravity trade on the Gini coefficient. The figure is based on equation (2); dashed lines are 95 percent confidence intervals. 
Table 1: Variance of Gravity Trade and Non-Gravity Trade

\begin{tabular}{|c|c|c|c|c|c|c|c|c|c|}
\hline & (1) & (2) & (3) & (4) & (5) & (6) & (7) & (8) & (9) \\
\hline \multicolumn{10}{|c|}{ Panel A: Full Sample } \\
\hline Non - Gravity Trade & 0.273 & 0.286 & 0.275 & 0.282 & 0.275 & 0.363 & 0.273 & 0.290 & 0.450 \\
\hline Gravity Trade & 0.001 & 0.011 & 0.007 & 0.017 & 0.001 & 0.020 & 0.001 & 0.019 & 0.046 \\
\hline \multicolumn{10}{|c|}{ Panel B: Pre-1990 Period } \\
\hline Non - Gravity Trade & 0.106 & 0.123 & 0.111 & 0.125 & 0.111 & 0.251 & 0.106 & 0.142 & 0.456 \\
\hline Gravity Trade & 0.001 & 0.012 & 0.010 & 0.019 & 0.010 & 0.038 & 0.001 & 0.032 & 0.079 \\
\hline \multicolumn{10}{|c|}{ Panel C: Post-1990 Period } \\
\hline Non - Gravity Trade & 0.288 & 0.300 & 0.289 & 0.296 & 0.289 & 0.374 & 0.288 & 0.303 & 0.449 \\
\hline Gravity Trade & 0.001 & 0.011 & 0.001 & 0.016 & 0.006 & 0.001 & 0.001 & 0.017 & 0.043 \\
\hline \multicolumn{10}{|c|}{ Panel D: High Income Countries } \\
\hline Non - Gravity Trade & 0.110 & 0.126 & 0.119 & 0.123 & 0.119 & 0.109 & 0.169 & 0.169 & 0.500 \\
\hline Gravity Trade & 0.001 & 0.009 & 0.015 & 0.009 & 0.007 & 0.001 & 0.044 & 0.045 & 0.044 \\
\hline \multicolumn{10}{|c|}{ Panel E: Middle Income Countries } \\
\hline Non - Gravity Trade & 0.188 & 0.186 & 0.189 & 0.205 & 0.189 & 0.269 & 0.187 & 0.199 & 0.505 \\
\hline Gravity Trade & 0.001 & 0.012 & 0.011 & 0.022 & 0.011 & 0.012 & 0.001 & 0.024 & 0.043 \\
\hline \multicolumn{10}{|c|}{ Panel F: Low Income Countries } \\
\hline Non - Gravity Trade & 0.338 & 0.354 & 0.339 & 0.344 & 0.339 & 0.451 & 0.339 & 0.345 & 0.423 \\
\hline Gravity Trade & 0.001 & 0.010 & 0.005 & 0.016 & 0.005 & 0.026 & 0.001 & 0.010 & 0.047 \\
\hline
\end{tabular}

Note: The table reports the within-country variances of non-gravity trade and gravity trade. Low, middle, and high-income countries are defined according to the World Bank classification. The variables in the gravity equation are as follows: column (1) log of distance and log of population size; column (2) log of distance and log of real GDP. In column (3) the variables in the gravity equation are the same as in Head et al. (2010) -- our benchmark model; column (4) adds to the benchmark model a dummy variable for countries which use US dollars as an official currency following Novy (2013); column (5) adds to the benchmark model a dummy variable for multilateral trade agreements with the US; column (6) adds to the benchmark model genetic distance (see: Spolaore and Wacziarg) from the US. In column (7) the variables entering the gravity model are the same as in Frankel and Romer (1999); column (8) Helpman et al (2008); and column (9) Baldwin and Harrigan (2011). 
Table 2. Non-Gravity Trade and Income Inequality

\begin{tabular}{|c|c|c|c|c|c|}
\hline Dependent Variable is: & Gini & $\begin{array}{c}\text { Income Share } \\
\text { Top } 10^{\text {th }} \\
\text { Percentile }\end{array}$ & $\begin{array}{l}\text { Income Share } \\
\text { Top } 20^{\text {th }} \\
\text { Percentile }\end{array}$ & $\begin{array}{l}\text { Income Share } \\
\text { Bottom } 20^{\text {th }} \\
\text { Percentile }\end{array}$ & $\begin{array}{c}\text { Income Share } \\
\text { Bottom } 10^{\text {th }} \\
\text { Percentile }\end{array}$ \\
\hline & (1) & (2) & (3) & (4) & (5) \\
\hline & \multicolumn{5}{|c|}{ Panel A: Two-Stage Least Squares } \\
\hline \multirow[t]{2}{*}{ Non-Gravity Trade } & $\begin{array}{c}4.04 * * * \\
(0.79)\end{array}$ & $\begin{array}{c}2.89 * * * \\
(0.59)\end{array}$ & $\begin{array}{c}3.17 * * * \\
(0.64)\end{array}$ & $\begin{array}{c}-0.99 * * * \\
(0.19)\end{array}$ & $\begin{array}{c}-0.51 * * * \\
(0.09)\end{array}$ \\
\hline & \multicolumn{5}{|c|}{ First Stage: Non-Gravity Trade } \\
\hline \multirow[t]{2}{*}{$\begin{array}{l}\text { Average Import Tariff, } \\
\text { Imposed by United } \\
\text { States on Country i }\end{array}$} & $\begin{array}{c}-0.22 * * * \\
(0.03)\end{array}$ & $\begin{array}{c}-0.22 * * * \\
(0.03)\end{array}$ & $\begin{array}{c}-0.22 * * * \\
(0.03)\end{array}$ & $\begin{array}{c}-0.22 * * * \\
(0.03)\end{array}$ & $\begin{array}{c}-0.22 * * * \\
(0.03)\end{array}$ \\
\hline & \multicolumn{5}{|c|}{ Panel B: Least Squares } \\
\hline Non-Gravity Trade & $\begin{array}{c}0.95 * * * \\
(0.23)\end{array}$ & $\begin{array}{c}0.72 * * * \\
(0.19)\end{array}$ & $\begin{array}{c}0.81 * * * \\
(0.20)\end{array}$ & $\begin{array}{c}-0.20 * * * \\
(0.05)\end{array}$ & $\begin{array}{c}-0.11 * * * \\
(0.02)\end{array}$ \\
\hline Observations & 538 & 538 & 538 & 538 & 538 \\
\hline
\end{tabular}

Note: Robust standard errors are shown in parentheses. ${ }^{* * *},{ }^{* *}$ and $*$ denotes significance at the $1 \%, 5 \%$ and $10 \%$ level, respectively. Control variables (estimated coefficients not reported) are time fixed effects, quantity of education and quality of education. 
Table 3. Non-Gravity Trade and Income Inequality (Excluding Large Economies)

\begin{tabular}{|c|c|c|c|c|c|}
\hline Dependent Variable is: & Gini & $\begin{array}{c}\text { Income Share } \\
\text { Top } 10^{\text {th }} \\
\text { Percentile }\end{array}$ & $\begin{array}{c}\text { Income Share } \\
\text { Top } 20^{\text {th }} \\
\text { Percentile }\end{array}$ & $\begin{array}{c}\text { Income Share } \\
\text { Bottom } 20^{\text {th }} \\
\text { Percentile }\end{array}$ & $\begin{array}{c}\text { Income Share } \\
\text { Bottom } 10^{\text {th }} \\
\text { Percentile }\end{array}$ \\
\hline
\end{tabular}

\section{(1)}

(2)

(3)

(4)

(5)

Panel A: Two-Stage Least Squares

\begin{tabular}{cccccc} 
Non-Gravity Trade & $3.82 * * *$ & $2.75^{* * *}$ & $3.01 * * *$ & $-0.93 * * *$ & $-0.48 * * *$ \\
& $(0.80)$ & $(0.59)$ & $(0.63)$ & $(0.19)$ & $(0.09)$ \\
\hline
\end{tabular}

First Stage: Non-Gravity Trade

$\begin{array}{lccccc}\text { Average Import Tariff, } & -0.21 * * * & -0.21 * * * & -0.21 * * * & -0.21 * * * & -0.21 * * * \\ \text { Imposed by United } & (0.03) & (0.03) & (0.03) & (0.03) & (0.03)\end{array}$

States on Country i

Panel B: Least Squares

\begin{tabular}{lccccc} 
Non-Gravity Trade & $\begin{array}{c}0.94 * * * \\
(0.23)\end{array}$ & $\begin{array}{c}0.74 * * * \\
(0.19)\end{array}$ & $\begin{array}{c}0.82 * * * \\
(0.20)\end{array}$ & $\begin{array}{c}-0.19 * * * \\
(0.05)\end{array}$ & $\begin{array}{c}-0.10 * * * \\
(0.02)\end{array}$ \\
\hline Observations & 480 & 480 & 480 & 480 & 480 \\
\hline
\end{tabular}

Note: Robust standard errors are shown in parentheses. ***, ** and * denotes significance at the $1 \%, 5 \%$ and $10 \%$ level, respectively. Control variables (estimated coefficients not reported) are time fixed effects, quantity of education and quality of education. The excluded countries are China, Germany, Japan, and the United Kingdom. 
Table 4. Non-Gravity Trade and Income Inequality (Controlling for Gravity Trade)

\begin{tabular}{|c|c|c|c|c|c|}
\hline Dependent Variable is: & Gini & $\begin{array}{c}\text { Income Share } \\
\text { Top } 10^{\text {th }} \\
\text { Percentile }\end{array}$ & $\begin{array}{c}\text { Income Share } \\
\text { Top } 20^{\text {th }} \\
\text { Percentile }\end{array}$ & $\begin{array}{l}\text { Income Share } \\
\text { Bottom } 20^{\text {th }} \\
\text { Percentile }\end{array}$ & $\begin{array}{l}\text { Income Share } \\
\text { Bottom } 10^{\text {th }} \\
\text { Percentile }\end{array}$ \\
\hline & (1) & (2) & (3) & (4) & $(5)$ \\
\hline & \multicolumn{5}{|c|}{ Panel A: Two-Stage Least Squares } \\
\hline Non-Gravity Trade & $\begin{array}{c}4.20 * * * \\
(0.88)\end{array}$ & $\begin{array}{c}2.98 * * * \\
(0.66)\end{array}$ & $\begin{array}{c}3.29 * * * \\
(0.71)\end{array}$ & $\begin{array}{c}-1.04 * * * \\
(0.22)\end{array}$ & $\begin{array}{c}-0.53 * * * \\
(0.10)\end{array}$ \\
\hline \multirow[t]{2}{*}{ Gravity Trade } & $\begin{array}{l}-0.72 \\
(0.54)\end{array}$ & $\begin{array}{l}-0.34 \\
(0.39)\end{array}$ & $\begin{array}{l}-0.50 \\
(0.42)\end{array}$ & $\begin{array}{l}0.25^{*} \\
(0.13)\end{array}$ & $\begin{array}{c}0.13 * * \\
(0.06)\end{array}$ \\
\hline & \multicolumn{5}{|c|}{ First Stage: Non-Gravity Trade } \\
\hline \multirow{2}{*}{$\begin{array}{l}\text { Average Import Tariff, } \\
\text { Imposed by United } \\
\text { States on Country i }\end{array}$} & $\begin{array}{c}-0.20 * * * \\
(0.03)\end{array}$ & $\begin{array}{c}-0.20 * * * \\
(0.03)\end{array}$ & $\begin{array}{c}-0.20 * * * \\
(0.03)\end{array}$ & $\begin{array}{c}-0.20 * * * \\
(0.03)\end{array}$ & $\begin{array}{c}-0.20 * * * \\
(0.03)\end{array}$ \\
\hline & \multicolumn{5}{|c|}{ Panel B: Least Squares } \\
\hline Non-Gravity Trade & $\begin{array}{c}1.07 * * * \\
(0.24)\end{array}$ & $\begin{array}{c}0.83^{* * *} \\
(0.20)\end{array}$ & $\begin{array}{c}0.92 * * * \\
(0.21)\end{array}$ & $\begin{array}{c}-0.22 * * * \\
(0.05)\end{array}$ & $\begin{array}{c}-0.12 * * * \\
(0.03)\end{array}$ \\
\hline Gravity Trade & $\begin{array}{l}-0.09 \\
(0.44)\end{array}$ & $\begin{array}{c}0.06 \\
(0.33)\end{array}$ & $\begin{array}{l}-0.06 \\
(0.35)\end{array}$ & $\begin{array}{c}0.07 \\
(0.11)\end{array}$ & $\begin{array}{c}0.04 \\
(0.05)\end{array}$ \\
\hline Observations & 480 & 480 & 480 & 480 & 480 \\
\hline
\end{tabular}

Note: Robust standard errors are shown in parentheses. ${ }^{* *}, * *$ and $*$ denotes significance at the $1 \%, 5 \%$ and $10 \%$ level, respectively Control variables (estimated coefficients not reported) are time fixed effects, quantity of education and quality of education. China, Germany, Japan, and the United Kingdom are excluded from the sample. 
Table 5. Trade and Income Inequality (Multilateral Trade)

\begin{tabular}{|c|c|c|c|c|c|}
\hline $\begin{array}{l}\text { Dependent Variable } \\
\text { is: }\end{array}$ & Gini & $\begin{array}{c}\text { Income Share } \\
\text { Top } 10^{\text {th }} \\
\text { Percentile }\end{array}$ & $\begin{array}{c}\text { Income Share } \\
\text { Top } 20^{\text {th }} \\
\text { Percentile }\end{array}$ & $\begin{array}{c}\text { Income Share } \\
\text { Bottom } 20^{\text {th }} \\
\text { Percentile }\end{array}$ & $\begin{array}{c}\text { Income Share } \\
\text { Bottom } 10^{\text {th }} \\
\text { Percentile }\end{array}$ \\
\hline & (1) & (2) & (3) & (4) & (5) \\
\hline & \multicolumn{5}{|c|}{ Panel A: Largest Sample } \\
\hline Non-Gravity Trade & $\begin{array}{l}21.05^{*} \\
(10.91)\end{array}$ & $\begin{array}{l}12.06^{*} \\
(7.04)\end{array}$ & $\begin{array}{l}14.75^{*} \\
(8.10)\end{array}$ & $\begin{array}{c}-6.54 * * \\
(3.15)\end{array}$ & $\begin{array}{c}-3.21 * * \\
(1.59)\end{array}$ \\
\hline \multirow[t]{2}{*}{ Gravity Trade } & $\begin{array}{c}6.61 \\
(4.33)\end{array}$ & $\begin{array}{l}3.84 \\
(2.72)\end{array}$ & $\begin{array}{l}4.61 \\
(3.16)\end{array}$ & $\begin{array}{l}-2.06 \\
(1.38)\end{array}$ & $\begin{array}{l}-1.01 \\
(0.64)\end{array}$ \\
\hline & \multicolumn{5}{|c|}{ First Stage: Non-Gravity Trade } \\
\hline Oil Price Shock & $\begin{array}{c}-1.82 * * * \\
(0.56)\end{array}$ & $\begin{array}{c}-1.82 * * * \\
(0.56)\end{array}$ & $\begin{array}{c}-1.82 * * * \\
(0.56)\end{array}$ & $\begin{array}{c}-1.82 * * * \\
(0.56)\end{array}$ & $\begin{array}{c}-1.82 * * * \\
(0.56)\end{array}$ \\
\hline Country Fixed Effects & Yes & Yes & Yes & Yes & Yes \\
\hline Time Fixed Effects & Yes & Yes543 & Yes & Yes & Yes \\
\hline Observations & 543 & 543 & 543 & 543 & 543 \\
\hline
\end{tabular}

Panel B: Without Large Oil Importers and Exporters

\begin{tabular}{lccccc}
\hline & $(1)$ & $(2)$ & $(3)$ & $(4)$ & $(5)$ \\
\hline Non-Gravity Trade & $22.16^{*}$ & $12.62^{*}$ & $15.51^{*}$ & $-6.92 * *$ & $-3.39 * *$ \\
& $(11.57)$ & $(7.45)$ & $(8.56)$ & $(3.35)$ & $(1.69)$ \\
Gravity Trade & 7.21 & 4.13 & 5.02 & -2.27 & -1.11 \\
& $(4.85)$ & $(3.03)$ & $(3.53)$ & $(1.43)$ & $(0.72)$ \\
\hline \multirow{5}{*}{ Oil Price Shock } & $-1.75^{* * *}$ & $-1.75^{* * *}$ & $-1.75^{* * *}$ & $-1.75^{* * *}$ & $-1.75^{* * *}$ \\
& $(0.57)$ & $(0.57)$ & $(0.57)$ & $(0.57)$ & $(0.57)$ \\
Country Fixed Effects & Yes & Yes & Yes & Yes & Yes \\
Time Fixed Effects & Yes & Yes & Yes & Yes & Yes \\
\hline Observations & 528 & 528 & 528 & 528 & 528 \\
\hline
\end{tabular}

Note: Cluster robust standard errors are shown in parentheses. $* * *, * *$ and $*$ denotes significance at the $1 \%, 5 \%$ and $10 \%$ level, respectively 
Table 6: Trade, Education and the Income Gini

\begin{tabular}{lclc}
\hline & $(1)$ & & $(2)$ \\
\hline Non - Gravity Trade & $26.352 * * *$ & Gravity Trade & 5.921 \\
& $(1.419)$ & & $(3.563)$ \\
Quality of Education & $-11.253^{* *}$ & Quality of Education & $-15.510^{* * *}$ \\
& $(0.699)$ & & $(2.073)$ \\
Quantity of Education & $-0.193 * * *$ & Quantity of Education & -0.303 \\
& $(0.040)$ & Gravity Trade & $(0.196)$ \\
Non - Gravity Trade & $-3.100^{* * *}$ & $*$ Quality of Education & $-0.758^{* *}$ \\
$*$ Quality of Education & $(0.346)$ & Gravity Trade & $-0.333)$ \\
Non - Gravity Trade & $-0.112 * * *$ & $*$ Quantity of Education & $(0.029)$ \\
$*$ Quantity of Education & $(0.022)$ & $\mathrm{R}^{2}$ & 0.495 \\
\hline $\mathrm{R}^{2}$ & 0.519 & Observations & 635 \\
Observations & 635 & &
\end{tabular}


Table 7: Predicted Effects of Non-Gravity Trade on the Income Gini for Individual Countries

\begin{tabular}{|c|c|c|c|c|c|c|c|}
\hline Country & $\begin{array}{l}\text { Quantity of } \\
\text { Edu. }\end{array}$ & $\begin{array}{l}\text { Quality } \\
\text { of Edu. }\end{array}$ & $\begin{array}{l}\text { Predicted } \\
\text { Effect }\end{array}$ & Country & $\begin{array}{c}\text { Quantity of } \\
\text { Edu. }\end{array}$ & $\begin{array}{l}\text { Quality } \\
\text { of Edu. }\end{array}$ & $\begin{array}{c}\text { Predicted } \\
\text { Effect }\end{array}$ \\
\hline Morocco & 72.26 & 3.33 & $7.90 * * *$ & China & 92.5 & 4.94 & $0.63^{* *}$ \\
\hline Ghana & 70.62 & 3.6 & $7.25 * * *$ & Bulgaria & 96.8 & 4.79 & $0.61 * *$ \\
\hline South Africa & 91.96 & 3.09 & $6.43 * * *$ & Lithuania & 97.23 & 4.78 & $0.60 * *$ \\
\hline Peru & 92.18 & 3.13 & $6.28 * * *$ & Malaysia & 96.54 & 4.84 & $0.49^{* *}$ \\
\hline Nigeria & 66.72 & 4.15 & $5.98 * * *$ & Latvia & 97.74 & 4.8 & $0.48^{* *}$ \\
\hline Brazil & 83.16 & 3.58 & $5.90 * * *$ & Italy & 99.26 & 4.76 & $0.44^{* *}$ \\
\hline Philippines & 92.37 & 3.65 & $4.65 * * *$ & Russia Fed. & 95.5 & 4.92 & 0.36 \\
\hline Botswana & 96.01 & 3.64 & $4.274 * * *$ & Norway & 98.83 & 4.83 & 0.26 \\
\hline Albania & 92.3 & 3.79 & $4.23 * * *$ & Poland & 98.81 & 4.84 & 0.23 \\
\hline Colombia & 83.55 & 4.15 & $4.09 * * *$ & Ireland & 94.85 & 4.99 & 0.21 \\
\hline Turkey & 94.68 & 3.79 & $3.95 * * *$ & Spain & 99.67 & 4.83 & 0.17 \\
\hline Indonesia & 96.47 & 3.88 & $3.48 * * *$ & Hungary & 94.85 & 5.05 & 0.03 \\
\hline Jordan & 96.38 & 4.26 & $3.31 * * *$ & Slovenia & 96.98 & 4.99 & -0.02 \\
\hline Argentina & 98.43 & 3.92 & $3.13 * * *$ & Denmark & 97.91 & 4.96 & -0.03 \\
\hline Mexico & 96.71 & 4 & $3.08 * * *$ & Iceland & 98.59 & 4.94 & -0.04 \\
\hline Macedonia & 93.03 & 4.15 & $3.07 * * *$ & UK & 98.62 & 4.95 & -0.08 \\
\hline Egypt & 96.63 & 4.03 & $2.99 * * *$ & Slovak Rep. & 96.51 & 5.05 & -0.15 \\
\hline Tunisia & 94.43 & 4.13 & $2.93 * * *$ & Germany & 99.14 & 4.96 & -0.17 \\
\hline Iran & 92.6 & 4.22 & $2.85 * * *$ & Belgium & 97.24 & 5.04 & -0.2 \\
\hline Uruguay & 91.34 & 4.3 & $2.75 * * *$ & Australia & 96.21 & 5.09 & -0.24 \\
\hline India & 92.77 & 4.28 & $2.65 * * *$ & Switzerland & 98.75 & 5.01 & -0.28 \\
\hline Armenia & 88.69 & 4.43 & $2.64 * * *$ & Sweden & 98.74 & 5.01 & -0.28 \\
\hline Cyprus & 88.92 & 4.54 & $2.28 * * *$ & Netherland & 96.11 & 5.11 & -0.29 \\
\hline Chile & 93.68 & 4.05 & $3.26 * * *$ & France & 98.03 & 5.04 & -0.29 \\
\hline Moldova & 92.41 & 4.53 & $1.92 * * *$ & Canada & 96.47 & 5.13 & -0.39 \\
\hline Portugal & 92.02 & 4.56 & $1.87 * * *$ & Austria & 94.42 & 5.09 & -0.43 \\
\hline Luxembourg & 91.51 & 4.64 & $1.67 * * *$ & Swaziland & 97.02 & 5.14 & -0.49 \\
\hline Serbia & 97.35 & 4.45 & $1.61 * * *$ & Estonia & 96.82 & 5.19 & -0.63 \\
\hline Romania & 95.31 & 4.56 & $1.50 * * *$ & Finland & 98.57 & 5.13 & -0.63 \\
\hline Israel & 97.53 & 4.69 & $0.85 * * *$ & Japan & 99.92 & 5.31 & -1.34 \\
\hline Greece & 96.48 & 4.61 & $0.84 * * *$ & & & & \\
\hline
\end{tabular}


Table 8: Relative Wage Tradable and Non-Tradable Sector

\begin{tabular}{lclc}
\hline & $(1)$ & & $(2)$ \\
\hline Non - Gravity Trade & $29.531^{* * *}$ & Gravity Trade & 3.871 \\
& $(10.264)$ & & $(2.242)$ \\
Quality of Education & $1.693^{* *}$ & Quality of Education & 0.373 \\
& $(0.622)$ & & $(0.875)$ \\
Quantity of Education & $0.222^{* * *}$ & Quantity of Education & -0.241 \\
& $(0.063)$ & & $(0.187)$ \\
Non - Gravity Trade & $-1.990^{* *}$ & Gravity Trade & -0.142 \\
$*$ Quality of Education & $(0.775)$ & $*$ Quality of Education & $(0.126)$ \\
Non - Gravity Trade & $-0.229 * * *$ & Gravity Trade & -0.033 \\
$*$ Quantity of Education & $(0.010)$ & $*$ Quantity of Education & $(0.026)$ \\
\hline $\mathrm{R}^{2}$ & 0.728 & $\mathrm{R}^{2}$ & 0.160 \\
Observations & 31 & Observations & 31 \\
\hline The dependent variable is the ratio of the wage in manufacturing (Tradable) over the wage in the construction \\
sector (Non-Tradable). Bootstrapped standard errors (5000 repetitions) are shown in parenthesis. ${ }^{* * *}$ and ** \\
denotes significance at the 1\% and 5\% level, respectively. & &
\end{tabular}


Table 9: Alternative Measures of Quality of Education

\begin{tabular}{lccc}
\hline & $(1)$ & $(2)$ & $(3)$ \\
\hline Non - Gravity Trade & $26.356^{* * *}$ & $17.443^{* * *}$ & $14.554^{* * *}$ \\
& $(1.421)$ & $(1.633)$ & $(1.435)$ \\
Quality of Education & $-10.408^{* * *}$ & $-28.718^{* * *}$ & $-138.945^{* * *}$ \\
& $(0.669)$ & $(1.704)$ & $(6.542)$ \\
Quantity of Education & $-0.183^{* * *}$ & $-0.282^{* * *}$ & $-0.160^{* * *}$ \\
& $(0.048)$ & $(0.034)$ & $(0.033)$ \\
Non - Gravity Trade & $-2.624^{* * *}$ & $-11.219^{* * *}$ & $-26.723^{* * *}$ \\
$*$ Quality of Education & $(0.352)$ & $(0.919)$ & $(2.584)$ \\
Non - Gravity Trade & $-0.138^{* * *}$ & $-0.076^{* * *}$ & $-0.121^{* * *}$ \\
$*$ Quantity of Education & $(0.025)$ & $(0.023)$ & $(0.016)$ \\
\hline $\mathrm{R}^{2}$ & 0.507 & 0.506 & 0.388 \\
Observations & 635 & 635 & 635 \\
\hline
\end{tabular}

The dependent variable is the Gini. Measures of quality of education: (1) lower secondary school, (2) basic education, and (3) top education. Bootstrapped standard errors (5000 repetitions) are shown in parenthesis. *** denotes significance at the $1 \%$ level. 
Table 10: Alternative Measure of Income Inequality

\begin{tabular}{lcccc}
\hline & $(1)$ & $(2)$ & $(3)$ & $(4)$ \\
\hline Non - Gravity Trade & $-1.927 * * *$ & $-5.341^{* * *}$ & $22.129^{* * *}$ & $19.813^{* * *}$ \\
& $(0.196)$ & $(0.366)$ & $(1.320)$ & $(1.491)$ \\
Quality of Education & $0.932 * * *$ & $2.263 * * *$ & $-8.839 * * *$ & $-8.075^{* * *}$ \\
& $(0.029)$ & $(0.061)$ & $(0.261)$ & $(0.258)$ \\
Quantity of Education & $0.042 * * *$ & $0.029 * * *$ & $-0.208^{* * *}$ & $-0.209 * * *$ \\
& $(0.002)$ & $(0.005)$ & $(0.022)$ & $(0.024)$ \\
Non - Gravity Trade & $0.243 * * *$ & $0.627 * * *$ & $-3.062 * * *$ & $-2.702 * * *$ \\
* Quality of Education & $(0.017)$ & $(0.034)$ & $(0.169)$ & $(0.174)$ \\
Non - Gravity Trade & $0.068^{* * *}$ & $0.023 * * *$ & $-0.071 * * *$ & $-0.066^{* * *}$ \\
$*$ Quantity of Education & $(0.002)$ & $(0.004)$ & $(0.015)$ & $(0.016)$ \\
\hline $\mathrm{R}^{2}$ & 0.321 & 0.434 & 0.548 & 0.536 \\
Observations & 635 & 635 & 635 & 635 \\
\hline
\end{tabular}

The dependent variable is the income share held by: (1) the poorest $10 \%$, (2) the poorest $20 \%$, (3) the richest $20 \%$, and (4) the richest $10 \%$. Bootstrapped standard errors (5000 repetitions) are shown in parenthesis. ${ }^{* * *}$ denotes significance at the $1 \%$ level. 
Table 11: Different Time Periods

\begin{tabular}{lcccc}
\hline & $(1)$ & $(2)$ & $(3)$ & $(4)$ \\
\hline Non - Gravity Trade & $26.352^{* * *}$ & $27.469^{* * *}$ & $25.250^{* * *}$ & $25.755^{* * *}$ \\
& $(1.419)$ & $(1.290)$ & $(0.899)$ & $(0.919)$ \\
Quality of Education & $-11.253^{* * *}$ & $-10.315^{* * *}$ & $-10.322^{* * *}$ & $-9.762 * * *$ \\
& $(0.699)$ & $(0.289)$ & $(0.284)$ & $(0.267)$ \\
Quantity of Education & $-0.193^{* * *}$ & $-0.270^{* * *}$ & $-0.284 * * *$ & $-0.300^{* * *}$ \\
& $(0.040)$ & $(0.026)$ & $(0.028)$ & $(0.139)$ \\
Non - Gravity Trade & $-3.100^{* * *}$ & $-3.793^{* * *}$ & $-3.919^{* * *}$ & $-3.836^{* * *}$ \\
* Quality of Education & $(0.346)$ & $(0.174)$ & $(0.171)$ & $(0.140)$ \\
Non - Gravity Trade & $-0.112^{* * *}$ & $-0.092^{* * *}$ & $-0.063 * * *$ & $-0.074 * * *$ \\
$*$ Quantity of Education & $(0.022)$ & $(0.015)$ & $(0.011)$ & $(0.011)$ \\
\hline $\mathrm{R}^{2}$ & 0.519 & 0.565 & 0.589 & 0.585 \\
Observations & 635 & 584 & 467 & 344 \\
\hline
\end{tabular}

Subsamples: (1) 1981-2013, (2) 1990-2013, (3) 2000-2013, and (4) 2005-2013. Bootstrapped standard errors (5000 repetitions) are shown in parenthesis. ${ }^{* * *}$ denotes significance at the $1 \%$ level. 
Table 12: Additional Control Variables

\begin{tabular}{lccccc}
\hline & $(1)$ & $(2)$ & $(3)$ & $(4)$ & $(5)$ \\
\hline Non - Gravity Trade & $20.775^{* * *}$ & $20.698^{* * *}$ & $19.077 * * *$ & $17.943 * * *$ & $21.811^{* * *}$ \\
& $(1.804)$ & $(1.748)$ & $(1.683)$ & $(1.620)$ & $(1.793)$ \\
Quality of Education & $-10.500^{* * *}$ & $-10.868^{* * *}$ & $-10.727 * * *$ & $-9.869^{* * *}$ & $-10.000^{* * *}$ \\
& $(0.619)$ & $(0.610)$ & $(0.623)$ & $(0.286)$ & $(0.297)$ \\
Quantity of Education & $-0.139^{* *}$ & $-0.141^{* * *}$ & $-0.116^{* * *}$ & $-0.124 * * *$ & $-0.166 * * *$ \\
& $(0.033)$ & $(0.032)$ & $(0.035)$ & $(0.024)$ & $(0.027)$ \\
Non - Gravity Trade $*$ & $-1.445^{* * *}$ & $-1.402 * * *$ & $-1.662 * * *$ & $-1.929 * * *$ & $-1.749 * * *$ \\
Quality of Edu. & $(0.093)$ & $(0.102)$ & $(0.117)$ & $(0.073)$ & $(0.074)$ \\
Non - Gravity Trade* & $-0.121 * * *$ & $-0.123 * * *$ & $-0.097 * *$ & $-0.085 * * *$ & $-0.080^{* *}$ \\
Quantity of Edu. & $(0.021)$ & $(0.021)$ & $(0.021)$ & $(0.018)$ & $(0.018)$ \\
Control Variable & $-0.001 * * *$ & $-0.001 * * *$ & $-0.031 *$ & $0.024 *$ & $0.075 * * *$ \\
& $(0.000)$ & $(0.000)$ & $(0.014)$ & $(0.012)$ & $(0.007)$ \\
Control Variable $*$ & -0.001 & $-0.001 * * *$ & -0.005 & 0.037 & $-0.042 * * *$ \\
Non - Gravity Trade & $(0.001)$ & $(0.000)$ & $(0.024)$ & $(0.023)$ & $(0.015)$ \\
\hline $\mathrm{R}^{2}$ & 0.579 & 0.571 & 0.553 & 0.575 & 0.590 \\
Observations & 624 & 635 & 635 & 601 & 601 \\
\hline
\end{tabular}

The dependent variable is the Gini. Control Variable refers to: (1) GDP per capita, (2) capital-labour ratio, (3) internet users per 100 people, (4) industry value added as \% GDP, (5) service value added as \% of GDP. Bootstrapped standard errors (5000 repetitions) are shown in parenthesis. $* * *, * *$ and $*$ denotes significance at the $1 \%, 5 \%$ and $10 \%$ level, respectively 
Table 13: Continent Dummy Variables

\begin{tabular}{|c|c|c|c|c|c|}
\hline & (1) & (2) & (3) & (4) & (5) \\
\hline Non - Gravity Trade & $\begin{array}{l}21.016^{* * *} \\
(1.666)\end{array}$ & $\begin{array}{l}21.481 * * * \\
(1.614)\end{array}$ & $\begin{array}{l}21.873 * * * \\
(1.614)\end{array}$ & $\begin{array}{l}20.841 * * * \\
(1.609)\end{array}$ & $\begin{array}{l}20.787 * * * \\
(1.625)\end{array}$ \\
\hline Quality of Education & $\begin{array}{l}-6.374 * * * \\
(0.704)\end{array}$ & $\begin{array}{c}-6.679 * * * \\
(0.697)\end{array}$ & $\begin{array}{l}-7.648 * * * \\
(0.735)\end{array}$ & $\begin{array}{l}-6.093 * * * \\
(0.705)\end{array}$ & $\begin{array}{l}-6.101 * * * \\
(0.675)\end{array}$ \\
\hline Quantity of Education & $\begin{array}{l}-0.348 * * * \\
(0.034)\end{array}$ & $\begin{array}{c}-0.348 * * \\
(0.034)\end{array}$ & $\begin{array}{l}-0.324 * * * \\
(0.035)\end{array}$ & $\begin{array}{l}-0.351^{* * *} \\
(0.034)\end{array}$ & $\begin{array}{c}-0.321 * * * \\
(0.036)\end{array}$ \\
\hline $\begin{array}{l}\text { Non - Gravity Trade } \\
* \text { Quality of Education }\end{array}$ & $\begin{array}{l}-3.032 * * * \\
\quad(0.343)\end{array}$ & $\begin{array}{l}-3.109 * * * \\
\quad(0.341)\end{array}$ & $\begin{array}{l}-3.087 * * * \\
(0.339)\end{array}$ & $\begin{array}{l}-3.008^{* * *} \\
(0.343)\end{array}$ & $\begin{array}{l}-2.995^{* * *} \\
(0.350)\end{array}$ \\
\hline $\begin{array}{l}\text { Non - Gravity Trade } \\
\text { * Quantity of Education }\end{array}$ & $\begin{array}{l}-0.065^{* * * *} \\
(0.024)\end{array}$ & $\begin{array}{c}-0.065^{* * *} \\
\quad(0.023)\end{array}$ & $\begin{array}{l}-0.069 * * * \\
(0.023)\end{array}$ & $\begin{array}{l}-0.064 * * * \\
(0.023)\end{array}$ & $\begin{array}{c}-0.065^{* * * *} \\
(0.024)\end{array}$ \\
\hline Africa & $\begin{array}{r}-2.224 \\
(0.003)\end{array}$ & $\begin{array}{r}2.187^{*} \\
(0.626)\end{array}$ & $\begin{array}{l}-5.381 * * * \\
(0.638)\end{array}$ & $\begin{array}{r}-0.341 \\
(0.610)\end{array}$ & - \\
\hline Asia & $\begin{array}{l}-2.492 * * * \\
(0.754)\end{array}$ & $\begin{array}{l}2.019 * * * \\
(0.445)\end{array}$ & $\begin{array}{l}-5.265^{* * *} \\
(0.465)\end{array}$ & - & $\begin{array}{c}-1.587 * * * \\
(0.528)\end{array}$ \\
\hline America & $\begin{array}{c}4.487 * * * \\
(0.622)\end{array}$ & $\begin{array}{c}8.868 * * * \\
(0.438)\end{array}$ & s & $\begin{array}{l}6.396 * * * \\
(0.448)\end{array}$ & $\begin{array}{c}5.506 * * * \\
(0.518)\end{array}$ \\
\hline Europe & $\begin{array}{l}-5.197 * * * \\
(0.557)\end{array}$ & - & $\begin{array}{c}-7.431 * * * \\
(0.395)\end{array}$ & $\begin{array}{l}-3.534 * * * \\
(0.394)\end{array}$ & $\begin{array}{c}-4.398 * * * \\
(0.457)\end{array}$ \\
\hline Oceania & - & $\begin{array}{r}-1.328 \\
(0.998) \\
\end{array}$ & $\begin{array}{r}-0.948 \\
(0.958) \\
\end{array}$ & $\begin{array}{r}-0.836 \\
(0.987) \\
\end{array}$ & $\begin{array}{r}-0.798 \\
(0.938) \\
\end{array}$ \\
\hline $\begin{array}{l}\mathrm{R}^{2} \\
\text { Observations }\end{array}$ & $\begin{array}{c}0.596 \\
635\end{array}$ & $\begin{array}{c}0.578 \\
625\end{array}$ & 0.588 & 0.593 & 0.595 \\
\hline
\end{tabular}

Excluded Continent: (1) Oceania, (2) Europe, (3) America, (4) Asia, (5) Africa. Bootstrapped standard errors (5000 repetitions) are shown in parenthesis. $* * *$ denotes significance at the $1 \%$ level. 
Table 14: Upper and Lower 95\% Confidence Interval

\begin{tabular}{lccc}
\hline & $(1)$ & $(2)$ & $(3)$ \\
\hline & $\begin{array}{c}\text { Coefficients in } \\
\text { Gravity Equation }\end{array}$ & $\begin{array}{c}\text { Upper 95\% } \\
\text { Interval of } \\
\text { Coefficients in } \\
\text { Gravity Equation }\end{array}$ & $\begin{array}{c}\text { Lower 95\% } \\
\text { Interval of } \\
\text { Coefficients in } \\
\text { Gravity Equation }\end{array}$ \\
\hline Non - Gravity Trade & $26.352^{* * *}$ & $26.635^{* * *}$ & $\begin{array}{c}26.353 * * * \\
(1.63)\end{array}$ \\
Quality of Education & $(1.419)$ & $-11.114 * * *$ & $-11.252^{* * *}$ \\
& $-11.253^{* * *}$ & $(0.652)$ & $(0.647)$ \\
Quantity of Education & $(0.699)$ & $-0.207 * * *$ & $-0.193 * * *$ \\
Non - Gravity Trade & $-0.193^{* * *}$ & $(0.037)$ & $(0.038)$ \\
$*$ Quality of Education & $(0.040)$ & $-3.082^{* * *}$ & $-3.101 * * *$ \\
Non - Gravity Trade & $(0.346)$ & $(0.577)$ & $(0.353)$ \\
$*$ Quantity of Education & $-0.112^{* * *}$ & $-0.117 * * *$ & $-0.112^{* * *}$ \\
\hline $\mathrm{R}^{2}$ & $(0.022)$ & $(0.026)$ & $(0.024)$ \\
Observations & 0.507 & 0.521 & 0.519 \\
\hline
\end{tabular}

Note: Bootstrapped standard errors (5000 repetitions) are shown in parenthesis. ${ }^{* * *}$ denotes significance at the $1 \%$ level. 
Table 15: No Distinction Between Gravity and Non-gravity Trade

\begin{tabular}{|c|c|c|c|c|}
\hline & (1) & $(2)$ & (3) & (4) \\
\hline $\log ($ Bilateral Trade/GDP) & $\begin{array}{l}5.507 \\
(3.998)\end{array}$ & $\begin{array}{l}5.919 \\
(3.295)\end{array}$ & $\begin{array}{l}4.189 \\
(3.325)\end{array}$ & $\begin{array}{l}5.872 \\
(3.332)\end{array}$ \\
\hline Quality of Education & $\begin{array}{c}-16.641 * * * \\
(1.592)\end{array}$ & $\begin{array}{c}-16.640 * * * \\
(1.698)\end{array}$ & $\begin{array}{l}-15.416^{* * * *} \\
(1.598)\end{array}$ & $\begin{array}{l}-15.619 * * * \\
(2.085)\end{array}$ \\
\hline Quantity of Education & $\begin{array}{c}-0.334 * * * \\
(0.125)\end{array}$ & $\begin{array}{c}-0.372 * * * \\
(0.123)\end{array}$ & $\begin{array}{c}-0.269^{* *} \\
(0.113)\end{array}$ & $\begin{array}{c}-0.450 * * * \\
(0.195)\end{array}$ \\
\hline $\begin{array}{l}\log (\text { Bilateral Trade/GDP) } \\
* \text { Quality of Education }\end{array}$ & $\begin{array}{c}-0.929 * * * \\
(0.223)\end{array}$ & $\begin{array}{c}-0.874 * * * \\
(0.210)\end{array}$ & $\begin{array}{c}-0.786^{* * * *} \\
(0.202)\end{array}$ & $\begin{array}{c}-0.805 * * * \\
(0.263)\end{array}$ \\
\hline $\begin{array}{l}\log (\text { Bilateral Trade/GDP) } \\
* \text { Quantity of Education }\end{array}$ & $\begin{array}{r}-0.001 \\
(0.045)\end{array}$ & $\begin{array}{r}-0.007 \\
(0.022)\end{array}$ & $\begin{array}{l}0.005 \\
(0.020)\end{array}$ & $\begin{array}{r}-0.007 \\
(0.025)\end{array}$ \\
\hline $\log ($ Distance $)$ & - & $\begin{array}{l}0.091 \\
(0.623)\end{array}$ & $\begin{array}{r}-0.577 \\
(0.653)\end{array}$ & $\begin{array}{l}0.732 \\
(0.678)\end{array}$ \\
\hline $\log$ (Population) & - & $\begin{array}{r}-0.417 \\
(0.220)\end{array}$ & - & $\begin{array}{c}-1.562 * * * \\
(0.265)\end{array}$ \\
\hline $\log ($ real GDP) & - & - & $\begin{array}{c}-6.459 * * * \\
(1.421)\end{array}$ & - \\
\hline $\log ($ area $)$ & - & - & - & $\begin{array}{c}1.175 * * * \\
(0.125)\end{array}$ \\
\hline Border & - & - & - & $\begin{array}{l}2.250 \\
(2.236)\end{array}$ \\
\hline Locked & - & - & - & $\begin{array}{r}-0.747 \\
(0.762)\end{array}$ \\
\hline Language & - & - & - & $\begin{array}{r}-1.264 \\
(1.623)\end{array}$ \\
\hline Colonial & - & - & - & $\begin{array}{l}0.809 \\
(1.123)\end{array}$ \\
\hline Freetrade & - & - & - & $\begin{array}{r}-1.755 \\
(1.132)\end{array}$ \\
\hline $\begin{array}{l}\mathrm{R}^{2} \\
\text { Observations }\end{array}$ & $\begin{array}{c}0.539 \\
601\end{array}$ & $\begin{array}{c}0.541 \\
601\end{array}$ & $\begin{array}{c}0.553 \\
601\end{array}$ & $\begin{array}{c}0.576 \\
601\end{array}$ \\
\hline
\end{tabular}

Bootstrapped standard errors (5000 repetitions) are shown in parentheses. $* * *$ and $* *$ denotes significance at the $1 \%$ and $5 \%$ level, respectively. 
Table 16: Alternative Variables in the Gravity Equation

\begin{tabular}{|c|c|c|c|c|c|c|c|c|c|}
\hline & $(1)$ & $(2)$ & (3) & (4) & $(5)$ & (6) & (7) & (8) & (9) \\
\hline Non - Gravity Trade & $\begin{array}{c}26.352 * * * \\
(1.419)\end{array}$ & $\begin{array}{c}27.662 * * * \\
(1.869)\end{array}$ & $\begin{array}{l}29.078 * * * \\
(1.639)\end{array}$ & $\begin{array}{c}27.176 * * * \\
(1.376)\end{array}$ & $\begin{array}{c}26.776^{* * * *} \\
(1.565)\end{array}$ & $\begin{array}{c}27.121 * * * \\
(1.614)\end{array}$ & $\begin{array}{c}22.946 * * * \\
(1.614)\end{array}$ & $\begin{array}{c}27.245 * * * \\
(1.695)\end{array}$ & $\begin{array}{c}19.635 * * * \\
(1.626)\end{array}$ \\
\hline Quality of Education & $\begin{array}{c}-11.253 * * * \\
(0.699)\end{array}$ & $\begin{array}{c}-10.487 * * * \\
(0.695)\end{array}$ & $\begin{array}{c}-10.859 * * * \\
(0.636)\end{array}$ & $\begin{array}{c}-10.666^{* * *} \\
(0.562)\end{array}$ & $\begin{array}{c}-11.038 * * * \\
(0.653)\end{array}$ & $\begin{array}{c}-11.391 * * * \\
(0.656)\end{array}$ & $\begin{array}{c}-10.427 * * * \\
(0.666)\end{array}$ & $\begin{array}{c}-11.166^{* * *} \\
(0.648)\end{array}$ & $\begin{array}{c}-11.093 * * * \\
(0.655)\end{array}$ \\
\hline Quantity of Education & $\begin{array}{c}-0.193 * * * \\
(0.040)\end{array}$ & $\begin{array}{c}-0.235 * * * \\
(0.037)\end{array}$ & $\begin{array}{c}-0.336 * * * \\
(0.033)\end{array}$ & $\begin{array}{c}-0.147 * * \\
(0.065)\end{array}$ & $\begin{array}{c}-0.199 * * * \\
(0.038)\end{array}$ & $\begin{array}{c}-0.229 * * * \\
(0.039)\end{array}$ & $\begin{array}{c}-0.229 * * * \\
(0.038)\end{array}$ & $\begin{array}{c}-0.239 * * * \\
(0.038)\end{array}$ & $\begin{array}{c}-0.160 * * * \\
(0.036)\end{array}$ \\
\hline $\begin{array}{l}\text { Non - Gravity Trade } \\
* \text { Quality of Education }\end{array}$ & $\begin{array}{c}-3.100 * * * \\
(0.346)\end{array}$ & $\begin{array}{c}-3.086^{* * * *} \\
(0.355)\end{array}$ & $\begin{array}{c}-3.752 * * * \\
(0.196)\end{array}$ & $\begin{array}{l}-2.535 * * * \\
(0.382)\end{array}$ & $\begin{array}{c}-3.124 * * * \\
(1.565)\end{array}$ & $\begin{array}{c}-3.678 * * * \\
(0.368)\end{array}$ & $\begin{array}{c}-3.824 * * * * \\
(0.307)\end{array}$ & $\begin{array}{c}-2.175^{* * * *} \\
(0.317)\end{array}$ & $\begin{array}{c}-0.352 * * \\
(0.143)\end{array}$ \\
\hline $\begin{array}{l}\text { Non - Gravity Trade } \\
* \text { Quantity of Education }\end{array}$ & $\begin{array}{c}-0.112 * * \\
(0.022)\end{array}$ & $\begin{array}{l}-0.126^{* * * *} \\
\quad(0.028)\end{array}$ & $\begin{array}{l}0.117 * * * \\
\quad(0.018)\end{array}$ & $\begin{array}{l}-0.163 * * * \\
\quad(0.011)\end{array}$ & $\begin{array}{c}-0.116^{* * * *} \\
\quad(0.022)\end{array}$ & $\begin{array}{l}-0.089^{* * *} \\
(0.025)\end{array}$ & $\begin{array}{c}-0.039 * \\
(0.022)\end{array}$ & $\begin{array}{l}-0.168 * * * \\
(0.023)\end{array}$ & $\begin{array}{c}-0.182 * * * \\
(0.019)\end{array}$ \\
\hline $\mathrm{R}^{2}$ & 0.507 & 0.5 & 0.5 & 0.5 & 0.5 & 0.5 & 0.5 & 0.5 & 0.477 \\
\hline Observations & 635 & 635 & 635 & 635 & 635 & 617 & 635 & 635 & 635 \\
\hline
\end{tabular}

The dependent variable is the Gini. Non-gravity trade is generated as follows: (1) baseline, see equation (1) in the paper, (2) independent variables in the gravity equation: log of distance and log of population only, (3) independent variables in the gravity equation: log of distance and log of real GDP only, (4) adding to the baseline a dummy variable for countries which use US dollars as an official currency following Novy (2013), (5) including in the baseline a dummy variable for multilateral agreement with the US, (6) including in the baseline genetic distance (see: Spolaore and Wacziarg) from the US, (7) the gravity equation as specified in Frankel and Romer (1999), (8) Helpman et al $(2008)$, (9) Baldwin and Harrigan (2011). Bootstrapped standard errors (5000 repetitions) are shown in parenthesis. $* * *, * *$ and $*$ denotes significance at the $1 \%, 5 \%$ and $10 \%$ level, respectively. 
Table 17: Manufacturing Trade

\begin{tabular}{|c|c|c|c|c|c|c|c|c|c|}
\hline & (1) & (2) & 3) & (4) & (5) & 6) & (7) & 8) & (9) \\
\hline Non - & $\begin{array}{r}10.72 \\
(1.2\end{array}$ & $* *$ & $\begin{array}{r}13.1 \\
(3 .\end{array}$ & (1. & ** & $* *$ & (1. & $(0$ & ) \\
\hline Quality of Education & $\begin{array}{r}-11.40 \\
(0.2\end{array}$ & $\begin{array}{r}-11.33 \\
(0.2\end{array}$ & $\begin{array}{r}-11.0 \\
(0 .\end{array}$ & $\begin{array}{r}-11.0 \\
(0 .\end{array}$ & $\begin{array}{r}-11.6 \\
(0 .\end{array}$ & $\begin{array}{r}-12.5 \\
(0 .\end{array}$ & $\begin{array}{r}-11.4 \\
(0 .\end{array}$ & *** & $\begin{array}{r}-9.9 \\
(0\end{array}$ \\
\hline Qua & $\begin{array}{r}-0.1 \\
(0 .\end{array}$ & $\begin{array}{r}-0.2 \\
(0\end{array}$ & $\begin{array}{r}-0.2 \\
(0\end{array}$ & $\begin{array}{r}-0.1 \\
(0\end{array}$ & $\begin{array}{r}-0.1 \\
(0\end{array}$ & $\begin{array}{r}-0.1 \\
(0\end{array}$ & $\begin{array}{r}-0.1 \\
(0\end{array}$ & $\begin{array}{r}-0.2 \\
(0\end{array}$ & $\begin{array}{r}-0.2 \\
(0\end{array}$ \\
\hline $\begin{array}{l}\text { le } \\
\text { on }\end{array}$ & $\begin{array}{r}-0.47 \\
(0.1\end{array}$ & $\begin{array}{r}-0.38 \\
(0.0\end{array}$ & $\begin{array}{r}-0.37 \\
(0.1\end{array}$ & $\begin{array}{r}-0.53 \\
\quad(0.0\end{array}$ & $\begin{array}{r}-0.19 \\
(0.3\end{array}$ & $\begin{array}{r}-0.39 \\
\quad(0 .\end{array}$ & $\begin{array}{r}-0.39 \\
(0 .\end{array}$ & $\begin{array}{r}-0.9 \\
(0\end{array}$ & $\begin{array}{r}-0.8 \\
(0\end{array}$ \\
\hline $\begin{array}{l}\text { ade } \\
\text { ication }\end{array}$ & $\begin{array}{c}-0.088^{* * *} \\
(0.017)\end{array}$ & $\begin{array}{c}0.177 * * * \\
(0.015)\end{array}$ & $\begin{array}{c}-0.138^{* * *} \\
(0.031)\end{array}$ & $\begin{array}{r}-0.11 \\
\quad(0.0\end{array}$ & $\begin{array}{r}-0.16 \\
\quad(0.0\end{array}$ & $\begin{array}{r}-0.16 \\
\quad(0 .\end{array}$ & $\begin{array}{r}-0.23 \\
\quad(0 .\end{array}$ & $\begin{array}{r}-0.1 \\
\quad(0 .\end{array}$ & $\begin{array}{l}* * * \\
3)\end{array}$ \\
\hline & & & & & & & & & \\
\hline actoms & 527 & 521 & 527 & 527 & 527 & 527 & 527 & 527 & \\
\hline \multicolumn{10}{|c|}{$\begin{array}{l}\text { The table shows results for manufacturing trade. The dependent variable is the Gini. Non-gravity trade is generated as follows: (1) baseline, see equation (1) in the paper, (2) } \\
\text { independent variables in the gravity equation: log of distance and log of population only, (3) independent variables in the gravity equation: log of distance and log of real GDP } \\
\text { only, (4) adding to the baseline a dummy variable for countries which use US dollars as an official currency following Novy (2013), (5) including in the baseline a dummy } \\
\text { variable for multilateral agreement with the US, (6) including in the baseline genetic distance (see: Spolaore and Wacziarg) from the US, (7) the gravity equation as specified } \\
\text { in Frankel and Romer (1999), (8) Helpman et al (2008), (9) Baldwin and Harrigan (2011). Bootstrapped standard errors (5000 repetitions) are shown in parenthesis. ***, ** } \\
\text { and * denotes significance at the } 1 \%, 5 \% \text { and } 10 \% \text { level, respectively. }\end{array}$} \\
\hline
\end{tabular}


Table 18: Primary Commodities

\begin{tabular}{lccccccccc}
\hline & $(1)$ & $(2)$ & $(3)$ & $(4)$ & $(5)$ & $(6)$ & $(7)$ & $(8)$ & $(9)$ \\
\hline Non - Gravity Trade & $11.528^{* * *}$ & $17.216^{* * *}$ & $12.352^{* * *}$ & $10.790^{* * *}$ & $12.131^{* * *}$ & $10.352^{* * *}$ & $12.901^{* * *}$ & $13.295^{* * *}$ & $18.045^{* * *}$ \\
& $(1.457)$ & $(1.622)$ & $(3.298)$ & $(1.303)$ & $(1.403)$ & $(1.602)$ & $(1.436)$ & $(1.293)$ & $(1.237)$ \\
Quality of Education & $-11.180^{* * *}$ & $-11.116^{* * *}$ & $-10.733^{* * *}$ & $-11.503^{* * *}$ & $-10.956^{* * *}$ & $-11.604^{* * *}$ & $-11.220^{* * *}$ & $-10.959^{* * *}$ & $-9.780^{* * *}$ \\
& $(0.254)$ & $(0.244)$ & $(0.302)$ & $(0.460)$ & $(0.267)$ & $(0.275)$ & $(0.249)$ & $(0.243)$ & $(0.318)$ \\
Quantity of Education & -0.025 & -0.002 & $-0.088^{*}$ & $0.063^{*}$ & -0.032 & -0.037 & -0.096 & -0.117 & -0.157 \\
& $(0.026)$ & $(0.027)$ & $(0.041)$ & $(0.039)$ & $(0.026)$ & $(0.024)$ & $(0.091)$ & $(0.074)$ & $(0.086)$ \\
Non - Gravity Trade & -0.118 & 0.058 & $-0.188^{*}$ & 0.273 & -0.062 & -0.230 & -0.095 & 0.452 & -0.252 \\
$*$ Quality of Education & $(0.092)$ & $(0.095)$ & $(0.092)$ & $(0.169)$ & $(0.093)$ & $(0.094)$ & $(0.091)$ & $(0.1998)$ & $(0.187)$ \\
Non - Gravity Trade & $-0.114^{* * *}$ & $0.181^{* * *}$ & $-0.138^{* * *}$ & $-0.126^{* * *}$ & $-0.124^{* * *}$ & $-0.095^{* * *}$ & $-0.130^{* * *}$ & $-0.097 * * *$ & $-0.136^{* * *}$ \\
$*$ Quantity of Edu. & $(0.016)$ & $(0.018)$ & $(0.033)$ & $(0.017)$ & $(0.015)$ & $(0.014)$ & $(0.016)$ & $(0.014)$ & $(0.014)$ \\
\hline $\mathrm{R}^{2}$ & 0.457 & 0.505 & 0.493 & 0.456 & 0.499 & 0.502 & 0.502 & 0.514 & 0.517 \\
Observations & 527 & 527 & 527 & 527 & 527 & 527 & 527 & 527 & 527 \\
\hline
\end{tabular}

The table shows results for primary commodity trade. The dependent variable is the Gini. Non-gravity trade is generated as follows: (1) baseline, see equation (1) in the paper,

(2) independent variables in the gravity equation: $\log$ of distance and $\log$ of population only, (3) independent variables in the gravity equation: log of distance and log of real

GDP only, (4) adding to the baseline a dummy variable for countries which use US dollars as an official currency following Novy (2013), (5) including in the baseline a dummy variable for multilateral agreement with the US, (6) including in the baseline genetic distance (see: Spolaore and Wacziarg) from the US, (7) the gravity equation as specified in Frankel and Romer (1999), (8) Helpman et al (2008), (9) Baldwin and Harrigan (2011). Bootstrapped standard errors (5000 repetitions) are shown in parenthesis. ***,** and $*$ denotes significance at the $1 \%, 5 \%$ and $10 \%$ level, respectively. 
Table 19: Gravity Trade, Education, and Inequality

\begin{tabular}{|c|c|c|c|c|c|c|c|c|c|}
\hline & $(1)$ & $(2)$ & $(3)$ & $(4)$ & $(5)$ & (6) & $(7)$ & $(8)$ & (9) \\
\hline Gravity Trade & $\begin{array}{l}5.921 \\
(3.563)\end{array}$ & $\begin{array}{l}6.450 \\
(4.869)\end{array}$ & $\begin{array}{l}5.677 \\
(5.103)\end{array}$ & $\begin{array}{l}5.677 \\
(5.103)\end{array}$ & $\begin{array}{l}6.067 \\
(4.990)\end{array}$ & $\begin{array}{l}5.970 \\
(5.017)\end{array}$ & $\begin{array}{l}5.934 \\
(5.046)\end{array}$ & $\begin{array}{l}6.331 \\
(5.907)\end{array}$ & $\begin{array}{c}6.989 \\
(5.179)\end{array}$ \\
\hline Quality of Education & $\begin{array}{l}-15.510 * * * \\
(2.073)\end{array}$ & $\begin{array}{c}-15.966 * * * \\
(1.829)\end{array}$ & $\begin{array}{l}-16.767 * * * \\
(2.088)\end{array}$ & $\begin{array}{c}-16.767 * * * \\
(2.088)\end{array}$ & $\begin{array}{l}-15.725 * * * \\
(1.755)\end{array}$ & $\begin{array}{l}-15.597 * * * \\
(1.775)\end{array}$ & $\begin{array}{l}-15.546 * * * \\
(1.800)\end{array}$ & $\begin{array}{l}-18.151 * * * \\
(1.969)\end{array}$ & $\begin{array}{c}-18.257 * * * \\
(2.111)\end{array}$ \\
\hline Quantity of Education & $\begin{array}{l}-0.303 \\
(0.196)\end{array}$ & $\begin{array}{l}-0.317 \\
(0.333)\end{array}$ & $\begin{array}{l}-0.216 \\
(0.347)\end{array}$ & $\begin{array}{l}0.216 \\
(0.347)\end{array}$ & $\begin{array}{l}-0.304 \\
(0.341)\end{array}$ & $\begin{array}{l}-0.301 \\
(0.341)\end{array}$ & $\begin{array}{l}-0.304 \\
(0.342)\end{array}$ & $\begin{array}{l}-0.213 \\
(0.405)\end{array}$ & $\begin{array}{l}-0.250 \\
(0.342)\end{array}$ \\
\hline $\begin{array}{l}\text { Gravity Trade } \\
* \text { Quality of Education }\end{array}$ & $\begin{array}{c}-0.758 * * \\
(0.333)\end{array}$ & $\begin{array}{c}-0.811 * * \\
(0.326)\end{array}$ & $\begin{array}{c}-0.965 * * \\
(0.376)\end{array}$ & $\begin{array}{c}-0.966 * * \\
(0.376)\end{array}$ & $\begin{array}{c}-0.794 * * \\
(0.313)\end{array}$ & $\begin{array}{c}-0.777 * \\
(0.319)\end{array}$ & $\begin{array}{c}-0.750 * * \\
(0.322)\end{array}$ & $\begin{array}{c}-1.131 * * * \\
(0.347)\end{array}$ & $\begin{array}{c}-1.135 * * * \\
(0.376)\end{array}$ \\
\hline $\begin{array}{l}\text { Gravity Trade } \\
* \text { Quantity of Education }\end{array}$ & $\begin{array}{l}-0.014 \\
(0.029)\end{array}$ & $\begin{array}{l}0.017 \\
(0.050)\end{array}$ & $\begin{array}{l}-0.001 \\
(0.055)\end{array}$ & $\begin{array}{l}-0.000 \\
(0.055)\end{array}$ & $\begin{array}{l}-0.014 \\
(0.054)\end{array}$ & $\begin{array}{r}-0.013 \\
(0.054)\end{array}$ & $\begin{array}{r}-0.015 \\
(0.054)\end{array}$ & $\begin{array}{r}-0.001 \\
(0.063)\end{array}$ & $\begin{array}{r}-0.005 \\
(0.055)\end{array}$ \\
\hline $\mathrm{R}^{2}$ & 0.495 & 0.494 & 0.498 & 0.498 & 0.497 & 0.496 & 0.494 & 0.514 & 0.505 \\
\hline Observations & 635 & 635 & 635 & 635 & 635 & 635 & 635 & 635 & 635 \\
\hline
\end{tabular}

The dependent variable is the Gini. Gravity trade is predicted trade: (1) baseline, see equation (1) in the paper, (2) independent variables in the gravity equation: log of distance and log of population only, (3) independent variables in the gravity equation: log of distance and log of real GDP only, (4) adding to the baseline a dummy variable for countries which use US dollars as an official currency following Novy (2013), (5) including in the baseline a dummy variable for multilateral agreement with the US, (6) including in the baseline genetic distance (see: Spolaore and Wacziarg) from the US, (7) the gravity equation as specified in Frankel and Romer (1999), (8) Helpman et al (2008), (9) Baldwin and Harrigan (2011). Bootstrapped standard errors (5000 repetitions) are shown in parenthesis. ***,** and * denotes significance at the $1 \%, 5 \%$ and $10 \%$ level, respectively. 
Data Appendix A Table A1. Description of Variables

\begin{tabular}{|c|c|c|}
\hline Variables & Description & Source \\
\hline Gravity Trade & $\begin{array}{l}\text { Predicted values of gravity equations } \\
\text { (detailed in Table } 1 \text { footnote) }\end{array}$ & \\
\hline $\begin{array}{l}\text { Non-Gravity } \\
\text { Trade }\end{array}$ & $\begin{array}{l}\text { Residual of gravity equations } \\
\text { (detailed in Table } 1 \text { footnote) }\end{array}$ & \\
\hline $\log \left(\frac{\text { Bilateral Trade }}{N G D P}\right)$ & $\begin{array}{l}\text { Logarithm of bilateral exports plus imports between country } i \\
\text { and the US divided by nominal gross domestic product } \\
\text { (measured in US dollars) of country } i \text {. }\end{array}$ & $\begin{array}{l}\text { The US Census } \\
\text { Bureau }\end{array}$ \\
\hline Population & $\begin{array}{l}\text { Country's } i \text { population. All residents regardless of legal status } \\
\text { or citizenship. }\end{array}$ & WDI \\
\hline Distance & $\begin{array}{l}\text { Distance of country } i \text { to the US (population-weighted great } \\
\text { circle distance between the largest cities of the two countries), } \\
\text { measure in kilometres. }\end{array}$ & CEPII \\
\hline Area & Country's area measure in square kilometres. & CEPII \\
\hline Border & $\begin{array}{l}\text { Dummy variable which takes the value of } 1 \text { if the country has } \\
\text { a border with the US and } 0 \text { otherwise. }\end{array}$ & CEPII \\
\hline Landlocked & $\begin{array}{l}\text { Dummy variable which takes the value of } 1 \text { if the country has } \\
\text { access to open sea and } 0 \text { otherwise. }\end{array}$ & CEPII \\
\hline Colonial & $\begin{array}{l}\text { Dummy variable which takes the value of } 1 \text { if country } i \text { has } \\
\text { been a British colony and } 0 \text { otherwise. }\end{array}$ & CEPII \\
\hline Free Trade & $\begin{array}{l}\text { Dummy variable which takes the value of } 1 \text { if country } i \text { has a } \\
\text { free trade agreement with the US and } 0 \text { otherwise (see dates in } \\
\text { table A2). }\end{array}$ & WTO \\
\hline $\begin{array}{l}\text { Official Currency } \\
\text { Pegged to U.S. } \\
\text { dollar }\end{array}$ & $\begin{array}{l}\text { Dummy variable which takes the value of } 1 \text { if the country of } \\
\text { reference has adopted the US dollar as an official currency and } \\
0 \text { otherwise. }\end{array}$ & $\begin{array}{l}\text { Ilzetski, Reinhart, } \\
\text { and Rogoff (2010) }\end{array}$ \\
\hline Legal System & $\begin{array}{l}\text { Dummy variable which takes the value of } 1 \text { if country } i \text { has } \\
\text { same the legal origin (British common law) than the U.S. and } \\
0 \text { otherwise. }\end{array}$ & CIA \\
\hline Religion & $\begin{array}{l}\text { Dummy variable which takes the value of } 1 \text { if country } i \text { has the } \\
\text { same religion majority than the US (Protestants) and } 0 \\
\text { otherwise. }\end{array}$ & CIA \\
\hline Island & $\begin{array}{l}\text { Dummy variable which takes the value of } 1 \text { if country } i \text { is an } \\
\text { island and } 0 \text { otherwise. }\end{array}$ & $\begin{array}{l}\text { World } \\
\text { Atlas }\end{array}$ \\
\hline Remoteness & $\begin{array}{l}\text { Market-size weighted sums of an inverse power function of } \\
\text { trade costs (see Balwin and Harrigan (2011)). }\end{array}$ & $\begin{array}{l}\text { Balwin and } \\
\text { Harrigan (2011) }\end{array}$ \\
\hline
\end{tabular}




\begin{tabular}{|c|c|c|}
\hline Wage Ratio & $\begin{array}{l}\text { Ratio of the wage in manufacturing (Tradable) over the wage } \\
\text { in the construction sector (Non-Tradable) for country } i \text {. }\end{array}$ & ILO \\
\hline Variables & Description & Source \\
\hline Gini & $\begin{array}{l}\text { Measure the extent to which the distribution of income among } \\
\text { individuals or households within an economy deviates from a } \\
\text { perfectly equal distribution. }\end{array}$ & WDI \\
\hline $\begin{array}{l}\text { Quantity of } \\
\text { Education } \\
\text { (Primary } \\
\text { Education's } \\
\text { Enrolment Rate) }\end{array}$ & $\begin{array}{l}\text { Total number of students of the official primary school age } \\
\text { group who are enrolled at primary education, expressed as a } \\
\text { percentage of the corresponding population. }\end{array}$ & WDI \\
\hline Cognitive Skills & $\begin{array}{l}\text { Average test score in math and science, primary through end of } \\
\text { secondary school, all years (scaled to PISA scale divided by } \\
\text { 100). }\end{array}$ & $\begin{array}{l}\text { Hanushek and } \\
\text { Woessmann (2009) }\end{array}$ \\
\hline Literacy Rate & $\begin{array}{l}\text { Percentage of people ages } 15 \text { and above who can both read and } \\
\text { write with understanding of a short simple statement about their } \\
\text { everyday life (Intertemporal average). }\end{array}$ & UNESCO and WTI \\
\hline $\begin{array}{l}\text { Lower Secondary } \\
\text { Education }\end{array}$ & $\begin{array}{l}\text { Average test score in math and science, only lower secondary, } \\
\text { all years (scaled to PISA scale divided by 100). }\end{array}$ & $\begin{array}{l}\text { Hanushek and } \\
\text { Woessmann (2009) }\end{array}$ \\
\hline Basic Education & $\begin{array}{l}\text { Share of students reaching basic literacy (based on average test } \\
\text { scores in math and science, primary through end of secondary } \\
\text { school, all years). }\end{array}$ & $\begin{array}{l}\text { Hanushek and } \\
\text { Woessmann (2009) }\end{array}$ \\
\hline Top Education & $\begin{array}{l}\text { Share of top-performing students (based on average test scores } \\
\text { in math and science, primary through end of secondary school, } \\
\text { all years). }\end{array}$ & $\begin{array}{l}\text { Hanushek and } \\
\text { Woessmann (2009) }\end{array}$ \\
\hline L10 & Percentage share of income of the poorest $10 \%$ of population. & WDI \\
\hline L20 & Percentage share of income of the poorest $20 \%$ of population. & WDI \\
\hline $\mathrm{H} 20$ & Percentage share of income of the richest $20 \%$ of population. & WDI \\
\hline $\mathrm{H} 10$ & Percentage share of income of the richest $10 \%$ of population. & WDI \\
\hline GDP per Capita & $\begin{array}{l}\text { Gross domestic product divided by midyear population. } \\
\text { Data are in current U.S. dollars. }\end{array}$ & VDI \\
\hline GDP per Worker & $\begin{array}{l}\text { Gross domestic product divided by total employment in the } \\
\text { economy converted to } 2011 \text { constant international dollars } \\
\text { using (power purchase parity) rates. }\end{array}$ & VDI \\
\hline Poverty at $\$ 1.9$ & $\begin{array}{l}\text { Percentage of the population living on less than } \$ 1.19 \text { a } \\
\text { day at } 2011 \text { international prices. }\end{array}$ & VDI \\
\hline Poverty at $\$ 3.1$ & $\begin{array}{l}\text { Percentage of the population living on less than } \$ 3.1 \text { a day } \\
\text { at } 2011 \text { international prices. }\end{array}$ & VDI \\
\hline Poverty at $\$ 5.2$ & $\begin{array}{l}\text { Percentage of the population living on less than } \$ 5.2 \text { a day } \\
\text { at } 2011 \text { international prices. }\end{array}$ & VDI \\
\hline
\end{tabular}




\begin{tabular}{|c|c|c|}
\hline Variables & Description & Source \\
\hline $\begin{array}{l}\text { Capital-Labour } \\
\text { Ratio }\end{array}$ & $\begin{array}{l}\text { Is approximated by multiplying gross capital formation } \\
\text { (as \% of gross domestic product) times gross domestic } \\
\text { product in term } 2011 \text { international dollars. }\end{array}$ & WDI \\
\hline $\begin{array}{l}\text { Internet Users } \\
\text { (per } 100 \text { people) }\end{array}$ & $\begin{array}{l}\text { Internet users are individuals who have used the Internet } \\
\text { (from any location) in the last } 12 \text { months. Internet can be } \\
\text { used via a computer, mobile phone, and personal digital } \\
\text { assistance. }\end{array}$ & WDI \\
\hline $\begin{array}{l}\text { Industry, Value } \\
\text { Added }(\% \text { of } \\
\text { GDP) }\end{array}$ & $\begin{array}{l}\text { Value added in: mining, manufacturing, construction, } \\
\text { electricity, water, and gas as percentage of gross domestic } \\
\text { product. }\end{array}$ & WDI \\
\hline $\begin{array}{l}\text { Service, Value } \\
\text { Added }(\% \text { of } \\
\text { GDP })\end{array}$ & $\begin{array}{l}\text { Value added in wholesale and retail trade (including hotels } \\
\text { and restaurants) as percentage in gross domestic product. }\end{array}$ & WDI \\
\hline $\begin{array}{l}\text { Total Trade }(\% \text { of } \\
\text { GDP })\end{array}$ & $\begin{array}{l}\text { Trade is the sum of exports and imports of goods and } \\
\text { services measured as a share of gross domestic product. }\end{array}$ & WDI \\
\hline $\begin{array}{l}\text { Exports }(\% \text { of } \\
\text { GDP) }\end{array}$ & $\begin{array}{l}\text { Exports of goods and services measured as a share of gross } \\
\text { domestic product. }\end{array}$ & WDI \\
\hline $\begin{array}{l}\text { Imports }(\% \text { of } \\
\text { GDP) }\end{array}$ & $\begin{array}{l}\text { Imports of goods and services measured as a share of gross } \\
\text { domestic product. }\end{array}$ & WDI \\
\hline $\log \left(\frac{\text { Bil.Man.Trade }}{N G D P}\right)_{i}$ & $\begin{array}{l}\text { Logarithm of bilateral exports plus imports in } \\
\text { manufacturing products between country } i \text { and the US } \\
\text { divided by nominal gross domestic product. }\end{array}$ & $\begin{array}{l}\text { The US Census } \\
\text { Bureau }\end{array}$ \\
\hline $\log \left(\frac{\text { Bil.Com.Trade }}{N G D P}\right)_{i}$ & $\begin{array}{l}\text { Logarithm of bilateral exports plus imports in } \\
\text { manufacturing products between country } i \text { and the US } \\
\text { divided by nominal gross domestic product. }\end{array}$ & $\begin{array}{l}\text { The US Census } \\
\text { Bureau }\end{array}$ \\
\hline
\end{tabular}


Data Appendix Table A2. List of Countries (Equation 1)

\begin{tabular}{|c|c|c|c|}
\hline Albania & El Salvador & Malawi & Sri Lanka \\
\hline Algeria & Estonia & Malaysia & St. Lucia \\
\hline Angola & Ethiopia & Maldives & Sudan \\
\hline Argentina & Fiji & Mali & Suriname \\
\hline Armenia & Finland & Mauritania & Swaziland \\
\hline Australia & France & Mauritius & Sweden \\
\hline Austria & Gabon & Mexico & Switzerland \\
\hline Azerbaijan & Gambia, The & Micronesia, Fed. Sts. & Syrian Arab Republic \\
\hline Bangladesh & Georgia & Moldova & Tajikistan \\
\hline Belarus & Germany & Mongolia & Tanzania \\
\hline Belgium & Ghana & Montenegro & Timor-Leste \\
\hline Belize & Greece & Morocco & Togo \\
\hline Benin & Guatemala & Mozambique & Tonga \\
\hline Bhutan & Guinea & Namibia & Trinidad and Tobago \\
\hline Bolivia & Guinea-Bissau & Nepal & Tunisia \\
\hline Bosnia and Herz. & Guyana & Netherlands & Turkey \\
\hline Botswana & Haiti & Nicaragua & Turkmenistan \\
\hline Brazil & Honduras & Niger & Uganda \\
\hline Bulgaria & Hungary & Nigeria & Ukraine \\
\hline Burkina Faso & Iceland & Norway & United Kingdom \\
\hline Burundi & India & Pakistan & Uruguay \\
\hline Cabo Verde & Indonesia & Palau & Uzbekistan \\
\hline Cambodia & Iran, Islamic Rep. & Panama & Venezuela, RB \\
\hline Cameroon & Ira & Papua New Guinea & Vietnam \\
\hline Canada & Ireland & Paraguay & Zambia \\
\hline Central African Rep. & Israel & Peru & \\
\hline Chad & Italy & Philippines & \\
\hline Chile & Jamaica & Poland & \\
\hline China & Japan & Portugal & \\
\hline Colombia & Jordan & Romania & \\
\hline Comoros & Kazakhstan & Russian Federation & \\
\hline Congo, Dem. Rep. & Kenya & Rwanda & \\
\hline Congo, Rep. & Kiribati & Samoa & \\
\hline Costa Rica & Kosovo & Sao Tome and Prin. & \\
\hline Cote d'Ivoire & Kyrgyz Republic & Senegal & \\
\hline Croatia & Lao PDR & Serbia & \\
\hline Cyprus & Latvia & Seychelles & \\
\hline Czech Republic & Lesotho & Sierra Leone & \\
\hline Denmark & Liberia & Slovak Republic & \\
\hline Djibouti & Lithuania & Slovenia & \\
\hline Dominican Republic & Luxembourg & Solomon Islands & \\
\hline Ecuador & Macedonia, FYR & South Africa & \\
\hline Egypt, Arab Rep. & Madagascar & Spain & \\
\hline
\end{tabular}


Data Appendix Table A3. List of Countries (Equation 2)

\begin{tabular}{llll}
\hline Albania & Estonia & Latvia & Russia Federation \\
Argentina & Finland & Lithuania & Serbia \\
Armenia & France & Luxembourg & Slovak Republic \\
Australia & Germany & Macedonia & Slovenia \\
Austria & Ghana & Malaysia & South Africa \\
Belgium & Greece & Mexico & Spain \\
Botswana & Hungary & Moldova & Swaziland \\
Brazil & Iceland & Morocco & Sweden \\
Bulgaria & India & Netherland & Switzerland \\
Canada & Indonesia & Nigeria & Tunisia \\
Chile & Iran, Islamic Rep. & Norway & Turkey \\
China & Ireland & Peru & United Kingdom \\
Colombia & Israel & Philippines & Uruguay \\
Cyprus & Italy & Poland & \\
Denmark & Japan & Portugal & \\
Egypt, Arab Rep & Jordan & Romania & \\
\hline
\end{tabular}


Data Appendix Table A4. Descriptive Statistics

\begin{tabular}{lccccc} 
Variable & $\begin{array}{c}\text { Equation } \\
\text { Number }\end{array}$ & Mean & Minimum & Maximum & $\begin{array}{c}\text { Standard } \\
\text { Deviation }\end{array}$ \\
\hline $\begin{array}{l}\text { Dependent: } \\
\log \left(\frac{\text { Bilateral trade }}{\text { Nominal GDP }}\right)\end{array}$ & 1 & -7.72 & -1.21 & -15.77 & 2.69 \\
Gini & 2 & 39.83 & 16.23 & 99.91 & 10.30 \\
L20 & - & 6.274 & 0.26 & 13.37 & 2.326 \\
Independent Variables: & 1 & 15.71 & 11.00 & 21.03 & 1.84 \\
\hline Log(population) & 1 & 9.06 & 6.04 & 9.70 & 0.54 \\
Log(distance) & 1 & 11.85 & 6.13 & 16.61 & 2.09 \\
Log(area) & 2 & -0.14 & -4.15 & 4.16 & 1.63 \\
Non-Gravity Trade & 2 & -23.87 & -24.87 & -22.81 & 0.34 \\
Gravity Trade & & & & & \\
Quantity of Education & 2 & 85.17 & 33.39 & 99.92 & 16.10 \\
Quality of Education (Alternative Measures) & & & & \\
\hline Cognitive Skills & 2 & 4.51 & 3.09 & 5.31 & 0.55 \\
Lower Secondary Education & 2 & 4.49 & 2.68 & 5.39 & 0.59 \\
Basic Education & 2 & 0.75 & 0.18 & 0.97 & 0.20 \\
Top Education & 2 & 0.05 & 0.00 & 0.17 & 0.04 \\
\hline & & & & & \\
\hline & & & & & \\
\hline
\end{tabular}

Appendix B 
Table B1: Determinants of Bilateral Trade/GDP

\begin{tabular}{ll}
\hline Log(Population) & $1.014^{* * *}$ \\
& $(0.039)$ \\
Log(Distance) & {$[0.013]$} \\
& $-1.656^{* * *}$ \\
& $(0.092)$ \\
Log(Area) & {$[0.027]$} \\
& $-0.073^{* *}$ \\
& $(0.032)$ \\
Border & {$[0.009]$} \\
& 0.122 \\
& $(0.394)$ \\
Locked & {$[0.147]$} \\
& $-1.019^{* * *}$ \\
Language & $(0.151)$ \\
& {$[0.036]$} \\
& $0.627 * * *$ \\
Colonial & $(0.222)$ \\
Periods (Years) & {$[0.05]$} \\
Cross section (Countries) & -0.197 \\
Freetrade & $(0.152)$ \\
& {$[0.037]$} \\
Adj R2 & $1.008^{* * *}$ \\
Observations & $(0.245)$ \\
& {$[0.147]$} \\
\hline & 0.632 \\
& 0.629 \\
& 1171 \\
& 29 \\
& 154 \\
\hline & \\
& \\
&
\end{tabular}

Note: Huber robust standard errors are shown in parentheses. Bootstrapped standard errors (5000 repetitions) are shown in brackets. ${ }^{* *}$ and $* *$ denotes significance at the $1 \%$ and $5 \%$ level, respectively. 
Appendix Figure 1. Effects of Non-Gravity Trade and Gravity Trade on the Tradable-to-NonTradable Wage Ratio

\section{Panel A: Non-Gravity Trade}
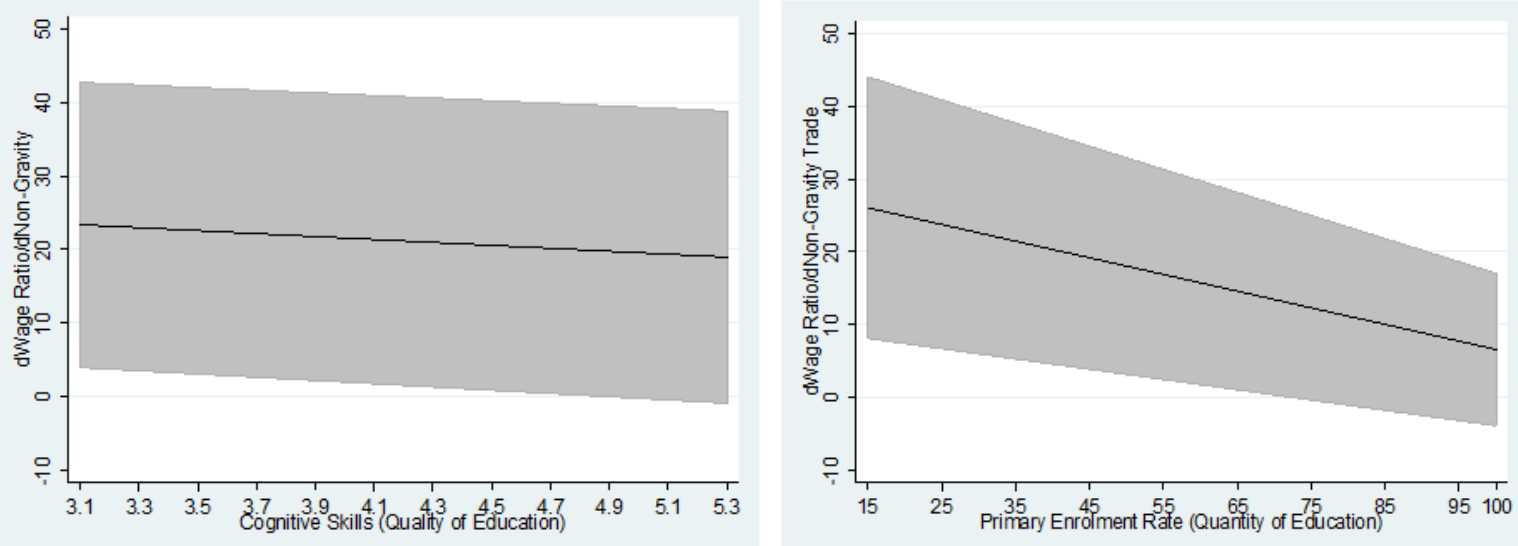

Panel B: Gravity Trade
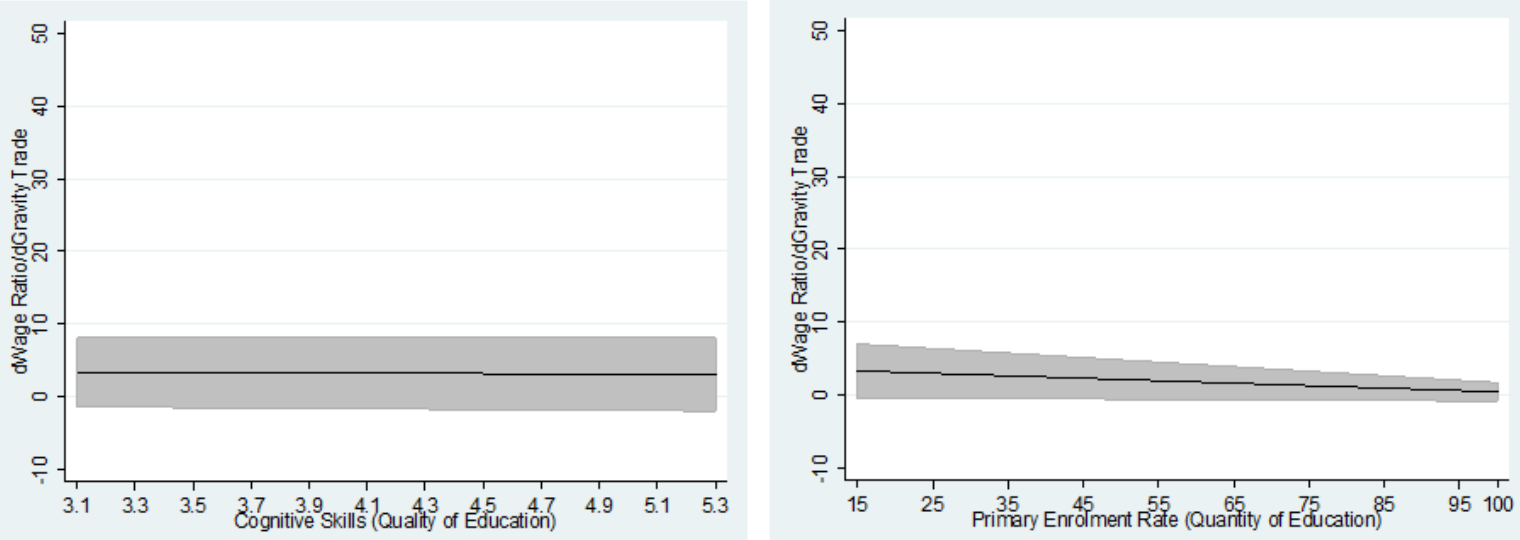


\section{APPENDIX \\ Effects of unanticipated trade shocks on sectoral outputs and wages}

In this Appendix, we show how trade shocks may affect wages and create inequality in a small open economy with imperfect labor mobility.

We begin with the benchmark case of perfect labor mobility and show how trade shocks affect outputs and factor incomes. Afterwards, we modify the model by assuming imperfect labor mobility.

\section{A benchmark 3-sector model with perfect labor mobility}

The home country (called Home for short) is a small open economy: it takes international prices as given. The rest of the world is called "The Foreign Country" or simply Foreign. Home produces three goods: $\operatorname{good} X$, good $M$ and $\operatorname{good} N$. Good $N$ is a non-traded good, while goods $X$ and $M$ are international traded. We assume perfect competition. Goods produced by different countries are perfect substitutes. Assume that in equilibrium, Home exports good $X$ and imports good $M$. The international prices (in US dollars) in Foreign are $P_{X}^{*}$ and $P_{M}^{*}$. Trading between Home and Foreign involves positive trade costs (such as inspection costs, bureaucratic delays, transport costs). These are denoted by $\tau_{X}>1$ and $\tau_{M}>1$, such that Home producers of good $X$ only receive $P_{X}$ (in US dollars) per unit exported, where $P_{X}=P_{X}^{*} / \tau_{X}<P_{X}^{*}$, and Home consumers must pay a price of $P_{M}$ (in US dollars) per unit of the imported good, where $P_{M}=\tau_{M} P_{M}^{*}>P_{M}^{*}$.

Import-competing firms in Home can sell good $M$ to Home's consumers at the price $P_{M}$ (in US dollars). Similarly, Home producers of good $X$ can (if they wish) sell their goods in the Home market at the price $P_{X}$ (in US dollars). The firms in the tradeable goods sector in the Home Country thus face the price ratio $\pi$, defined by

$$
\pi=\frac{P_{X}}{P_{M}}=\frac{P_{X}^{*}}{\tau_{X} \tau_{M} P_{M}^{*}} .
$$

Since $P_{X}^{*}$ and $P_{M}^{*}$ are given, a fall in either $\tau_{X}$ or $\tau_{M}$ (or both) will increase $\pi$. In the home market, there are three price ratios: $\pi, p$ and $q$, where $p$ denotes the domestic price ratio of good $X$ to good $N$, and $q$ denotes the price ratio of good $M$ to $\operatorname{good} N$. The domestic price ratio of exportables to importables is $p / q=\pi$. We assume that in the non-traded good industry the marginal product of labor is constant, and is equal to 1 . It follows that in Home's non-traded good sector, the wage rate, measured in terms of the non-traded good, is $W=1$. The other two 
sectors, producing good $X$ and $M$ respectively, use sector-specific capital $K_{X}$ and $K_{M}$ and mobile labor, $L_{X}$ and $L_{M}$. The total labor force is $L$, and full employment implies that $L_{N}+L_{X}+L_{M}=L .{ }^{1}$

Let $Q_{N}, Q_{M}$ and $Q_{X}$ denote Home's output of goods $N, M$ and $X$ respectively. We assume that the production functions are

$$
\begin{gathered}
Q_{N}=L_{N}, \\
Q_{M}=F^{M}\left(L_{M}, K_{M}\right), \\
Q_{X}=F^{X}\left(L_{X}, K_{X}\right) .
\end{gathered}
$$

where $F^{X}($.$) and F^{Y}($.$) are neoclassical productions with the usual properties. We$ assume that $K_{M}$ and $K_{X}$ are in fixed supply and these variables will be omitted in what follows. Thus we will use the following notations:

$$
Q_{X}=f\left(L_{X}\right) \text { and } Q_{M}=g\left(L_{M}\right),
$$

where $f($.$) and g($.$) are strictly concave and increasing.$

Assume that in equilibrium the outputs and labor inputs in all three sectors are strictly positive. Then, under perfect labor mobility (i.e., the wage rates in all the industries are equalized), production efficiency implies that $p f^{\prime}\left(L_{X}\right)=W$, and $q g^{\prime}\left(L_{M}\right)=W$, where $W=1$. Given $p$ and $q$, we can determine the allocation of labor across sector by using the following equations:

$$
\begin{gathered}
p f^{\prime}\left(L_{X}\right)=1 \rightarrow \frac{d L_{X}}{d p}=-\frac{f^{\prime}}{p f^{\prime \prime}}=-\frac{1}{p^{2} f^{\prime \prime}}>0, \\
q g^{\prime}\left(L_{M}\right)=1 \rightarrow \frac{d L_{M}}{d q}=-\frac{g^{\prime}}{q g^{\prime \prime}}=-\frac{1}{q^{2} g^{\prime \prime}}>0 .
\end{gathered}
$$

Note that

$$
\frac{p}{q}=\frac{g^{\prime}\left(L_{M}\right)}{f^{\prime}\left(L_{X}\right)} .
$$

From (1.4) and (1.5), we get

$$
Q_{X}=Q_{X}(p) \text {, and } Q_{X}^{\prime}(p)=f^{\prime}\left(L_{X}\right) \frac{d L_{X}}{d p}=-\frac{1}{p^{3} f^{\prime \prime}}
$$

\footnotetext{
${ }^{1}$ These assumptions are used in a number of well known papers (e.g., Grossman and Helpman, "Protection for Sale", American Economic Review, 84(4),1994, pp. 833-850).
} 


$$
\begin{gathered}
Q_{M}=Q_{M}(q), \text { and } Q_{M}^{\prime}(q)=-\frac{1}{q^{3} g^{\prime \prime}} \\
L_{N}=\bar{L}-L_{X}(p)-L_{M}(q), Q_{N}=L_{N}
\end{gathered}
$$

and national income in terms of good $N$ is

$$
\begin{aligned}
Y & =\left(\bar{L}-L_{X}(p)-L_{M}(q)\right)+p Q_{X}(p)+q Q_{M}(q) \\
& =\bar{L}+\left[p Q_{X}(p)-L_{X}(p)\right]+\left[q Q_{M}(q)-L_{M}(q)\right]
\end{aligned}
$$

On the demand side, we assume that consumers' utility function is quasi-linear:

$$
U\left(C_{M}, C_{X}, C_{N}\right)=u\left(C_{M}\right)+v\left(C_{X}\right)+C_{N}
$$

where $u($.$) and v($.$) are strictly concave functions. The representative consumer$ maximizes $U$ subject to

$$
p C_{X}+q C_{M}+C_{N}=E,
$$

where $E$ is total expenditure (in terms of good $N$ ). The Lagrangian is

$$
L=u\left(C_{M}\right)+v\left(C_{X}\right)+C_{N}+\lambda\left[E-p C_{X}-q C_{M}-C_{N}\right] .
$$

Assuming an interior solution. The FOCs are

$$
\begin{gathered}
u^{\prime}\left(C_{M}\right)=\lambda q, \\
v^{\prime}\left(C_{X}\right)=\lambda p, \\
1=\lambda .
\end{gathered}
$$

Thus we obtain the demand functions

$$
\begin{gathered}
C_{M}=u^{\prime-1}(q) \equiv D_{M}(q) \text { with } D_{M}^{\prime}(q)=\frac{1}{u^{\prime \prime}\left(C_{M}\right)}<0 \\
C_{X}=v^{\prime-1}(p) \equiv D_{X}(p) \text { with } D_{X}^{\prime}\left(C_{X}\right)=\frac{1}{v^{\prime \prime}\left(C_{X}\right)}<0 \\
C_{N}=E-q D_{M}(q)-p D_{X}(p)
\end{gathered}
$$

In equilibrium, the non-traded market must clear, i.e., $C_{N}=Q_{N}$. We assume that the total consumption expenditure equals income, $E=Y$. As is well 
known, this assumption implies that trade balance is zero. To see this, note that conditions $E=Y_{N}$ and $C_{N}=Q_{N}$ imply

$$
p D_{X}(p)+q D_{M}(q)=p Q_{X}(p)+q Q_{M}(q),
$$

i.e.,

$$
\left[D_{M}(q)-Q_{M}(q)\right]=\frac{p}{q}\left[Q_{X}(p)-D_{X}(p)\right]
$$

i.e.,

$$
M(q)-\frac{p}{q} X(p)=0
$$

where $M(q)$ is the imports demand function, $M(q) \equiv D_{M}(q)-Q_{M}(q)$, and $X(p) \equiv$ $Q_{X}(p)-D_{X}(p)$ is the export supply function.

\section{Effects of trade shocks on domestic relative prices}

Let us show that in our model, an increase in $\pi$ (which may be caused by a decrease in $\tau_{M}$ or in $\tau_{X}$, or an increase in the exogenous foreign price ratio, $P_{X}^{*} / P_{M}^{*}$ ) always leads to a fall in $q$ (the price of importables relative to the price of the non-traded good). Using $p=q \pi$, we write the trade balance condition (1.14) as

$$
G(\pi, q) \equiv M(q)-\pi X(q \pi)=0 .
$$

This equation implies that $q$ is a function of the exogenous parameter $\pi$. Applying the implicit function theorem to (1.15), we obtain

$$
\frac{d q}{d \pi}=-\frac{G_{\pi}}{G_{q}}=\frac{\left[\pi X^{\prime}(q \pi) q+X\right]}{M^{\prime}(q)-\pi^{2} X^{\prime}(q \pi)}=\frac{p X^{\prime}(p)+X}{M^{\prime}(q)-\frac{p^{2}}{q^{2}} X^{\prime}(p)}<0 .
$$

Thus, an increase in $\pi$ always reduces $q$, the price of importables in terms of the non-traded good.

To express this result in terms of various elasticities, let us re-arrange eq. (1.16) to get

$$
\begin{aligned}
\frac{d q}{d \pi} & =\frac{\left[\frac{p X^{\prime}}{X}+1\right]}{\left[\frac{M^{\prime}}{X}-\left(\frac{p}{q^{2}}\right)\left(\frac{p X^{\prime}}{X}\right)\right]}=\frac{\left[\frac{p X^{\prime}}{X}+1\right]}{\left[\frac{\pi M^{\prime}}{M}-\left(\frac{p}{q^{2}}\right)\left(\frac{p X^{\prime}}{X}\right)\right]} \\
& =\frac{\left[\frac{p X^{\prime}}{X}+1\right]}{\left[\frac{p q M^{\prime}}{q^{2} M}-\left(\frac{p}{q^{2}}\right)\left(\frac{p X^{\prime}}{X}\right)\right]}=\frac{\left[\frac{p X^{\prime}}{X}+1\right]}{\left(\frac{\pi}{q}\right)\left[\frac{q M^{\prime}}{M}-\frac{p X^{\prime}}{X}\right]}
\end{aligned}
$$


Then

$$
\frac{\pi}{q}\left(\frac{d q}{d \pi}\right)=-\frac{(\varepsilon+1)}{(\varepsilon+\mu)}<0
$$

where $\varepsilon \equiv \frac{p X^{\prime}}{X}>0$ is the price elasticity of exports and $\mu \equiv-\frac{q M^{\prime}(q)}{M}>0$ is the price elasticity of imports. From (1.17), we can state:

Lemma 1: An increase in $\pi$ always leads to a fall in the price of importables in terms of the non-traded goods, $q$, and therefore a fall in labor employment in sector $M$.

Lemma 2: An increase in $\pi$ may result in an increase or a decrease in $p$, the relative price of exportables in terms of the non-traded goods. The necessary and sufficient condition for $p$ to increase in response to an increase in $\pi$ is that the price elasticity of imports demand exceeds unity: $\mu>1$.

Proof: From $p=q \pi$, we get

$$
\frac{d p}{d \pi}=\pi \frac{d q}{d \pi}+q=q\left[\frac{\pi}{q} \frac{d q}{d \pi}+1\right]=q\left[1-\frac{(\varepsilon+1)}{(\varepsilon+\mu)}\right]=q\left[\frac{\mu-1}{\varepsilon+\mu}\right] .
$$

Thus

$$
\frac{d p}{d \pi}>0 \text { iff } \mu>1
$$

Then, in elasticity form,

$$
\frac{\pi}{p} \frac{d p}{d \pi}=\frac{\mu-1}{\varepsilon+\mu} .
$$

Remark 1: Since $p f^{\prime}\left(L_{X}\right)=1$, Lemma 2 shows that an increase in $\pi$ will increase employment in sector $X$ iff $\mu>1$.

Remark 2: Let us find some sufficient conditions for $\mu>1$. Recall that

$$
\mu \equiv-\frac{q}{M} \frac{d M}{d q}=\frac{q}{M}\left[Q_{M}^{\prime}(q)-D_{M}^{\prime}(q)\right]>0
$$

Using (1.8), and (1.11), we have

$$
\mu=\frac{q}{C_{M}-g\left(L_{M}(q)\right)}\left[-\frac{1}{q^{3} g^{\prime \prime}\left(L_{M}\right)}-\frac{1}{u^{\prime \prime}\left(C_{M}\right)}\right]
$$

Example: Suppose $g\left(L_{M}\right)=B L_{M}-\frac{1}{2} L_{M}^{2}$ and $u\left(C_{M}\right)=A C_{M}-\frac{1}{2} C_{M}^{2}$. Then $g^{\prime \prime}=-1=u^{\prime \prime}$, and

$$
\mu=\frac{q}{C_{M}-g\left(L_{M}(q)\right)}\left[\frac{1+q^{3}}{q^{3}}\right] .
$$


In this case a sufficient condition for $\mu>1$ is

$$
\frac{q}{C_{M}(q)-g\left(L_{M}(q)\right)}>1
$$

where

$$
q g^{\prime}\left(L_{M}\right)=1 \rightarrow B-L_{M}=1 / q
$$

Then

$$
\begin{gathered}
g\left(L_{M}(q)\right)=B\left(B-\frac{1}{q}\right)-\frac{1}{2}\left(B-\frac{1}{q}\right)^{2}=\frac{1}{2}\left(B-\frac{1}{q}\right)\left[B+\frac{1}{q}\right] \\
=\frac{1}{2}\left(B^{2}-\frac{1}{q^{2}}\right)>0 \text { for } q>1 / B \\
u^{\prime}\left(C_{M}\right)=q \rightarrow C_{M}=A-q>0 \text { for } q<A \\
\frac{q}{C_{M}(q)-g\left(L_{M}(q)\right)}=\frac{q}{A-q-\frac{B^{2}}{2}+\frac{1}{q^{2}}}>0 \text { if } q>0 \text { and } A-\frac{B^{2}}{2}>q-\frac{1}{2 q^{2}}
\end{gathered}
$$

Then , assuming $\frac{1}{B}<q<A, B>1 / A$, and $A-\frac{B^{2}}{2}>q-\frac{1}{2 q^{2}}$, we have the condition

$$
\frac{q}{C_{M}(q)-g\left(L_{M}(q)\right)} \geq 1 \Longleftrightarrow 2 q-\frac{1}{2 q^{2}}>A-\frac{B^{2}}{2}
$$

e.g., for $q=A / 2$, and $A>2 B>2 / A$, we have $\mu>1$.

\section{Effects of a trade shock on sectoral employments}

Assume perfect labor mobility across the three sectors, the equilibrium labour allocation is depicted in a diagram (Figure A.1) where the curve on the left measures the value of marginal product of labour in the exportable sector, $p f^{\prime}\left(L_{X}\right)$, while the curve on the right measures the value of marginal product of labor in the importable sector, $q g^{\prime}\left(L_{M}\right)$. These curves cut the horizontal line $W=1$ at points $I$ and $J$, where $J$ is to the right of $I$. The distance $I J$ measures the employment in the non-traded good sector.

The effects of an increase in $\pi$ on sectoral employment can be represented by shifts in the curves $p f^{\prime}\left(L_{X}\right)$ and $q g^{\prime}\left(L_{M}\right)$. Then, assuming $\mu>1$, an increase in $\pi$ will shift the curve $p f^{\prime}\left(L_{X}\right)$ up, and shift the curve $q g^{\prime}\left(L_{M}\right)$ down. Thus, $L_{X}$ increases and $L_{M}$ decreases. What happens to employment in the non-traded good sector? Since

$$
L_{N}=\bar{L}-L_{X}-L_{M}
$$


we have

$$
\frac{d L_{N}}{d \pi}=-\frac{d L_{X}}{d \pi}-\frac{d L_{M}}{d \pi}
$$

Now, from $p f^{\prime}\left(L_{X}\right)=1$, we have

$$
\begin{gathered}
f^{\prime}\left(L_{X}\right) d p+p f^{\prime \prime}\left(L_{X}\right) d L_{X}=0 \\
\frac{d L_{X}}{d p}=-\frac{f^{\prime}}{p f^{\prime \prime}}=-\frac{1}{p^{2} f^{\prime \prime}}>0
\end{gathered}
$$

Similarly

$$
\frac{d L_{M}}{d q}=-\frac{1}{q^{2} g^{\prime \prime}}>0
$$

Then

$$
\begin{gathered}
\frac{d L_{X}}{d \pi}=\frac{d L_{X}}{d p} \frac{d p}{d \pi}=-\frac{1}{p^{2} f^{\prime \prime}} q\left[\frac{\mu-1}{\varepsilon+\mu}\right]>0 \text { iff } \mu>1 \\
\frac{d L_{M}}{d \pi}=\frac{d L_{M}}{d q} \frac{d q}{d \pi}=\frac{1}{q^{2} g^{\prime \prime}} \frac{(\varepsilon+1) q}{(\varepsilon+\mu) \pi}<0
\end{gathered}
$$

Thus

$$
\begin{aligned}
& \frac{d L_{N}}{d \pi}=\frac{q}{\varepsilon+\mu}\left[\frac{\mu-1}{p^{2} f^{\prime \prime}}-\frac{(\varepsilon+1)}{\pi q^{2} g^{\prime \prime}}\right] \\
& =\frac{q}{(\varepsilon+\mu) p}\left[\frac{\mu-1}{p f^{\prime \prime}}-\frac{(\varepsilon+1)}{q g^{\prime \prime}}\right]
\end{aligned}
$$

Thus, employment in the non-traded good sector may increase or decrease (it increases if $\mu \leq 1)$.

\section{Effects of trade shocks on wage inequality when labor is imperfectly mobile}

In the preceeding section, we assume perfect mobility of labor, so that the wage rates in the three sectors are equalized. We now turn to the case where labor mobility is restricted in the short run.

Consider an initial situation where wages are equalized and are equal to unity, $W_{X}^{0}=W_{M}^{0}=W_{N}=1$. At that initial equilibrium, employments in sectors $X$ and $M$ are denoted by $L_{X}^{0}$ and $L_{M}^{0}$. 
Now, assume that there is a shock that increases $\pi$. Assume $\mu>1$. Then the shock shifts the curve $p f^{\prime}\left(L_{X}\right)$ up and shifts the curve $q g^{\prime}\left(L_{M}\right)$ down, because $p$ now takes a higher value, $p^{*}>p^{0}$, and $q$ now takes a lower value, $q^{*}<q^{0}$.

Since labor cannot move across sectors in the short run, the higher marginal value product of labor in sector $X$ results in a higher wage in that sector:

$$
W_{X}=p^{*} f^{\prime}\left(L_{X}^{0}\right)>p^{0} f^{\prime}\left(L_{X}^{0}\right)=W_{X}^{0}
$$

Similarly

$$
W_{M}=q^{*} g^{\prime}\left(L_{M}^{0}\right)<q^{0} g^{\prime}\left(L_{M}^{0}\right)=W_{M}^{0}
$$

The wage in the non-traded good sector remains unchanged, at $W_{N}=1$.

The wage inequality gives workers an incentive to move from the low wage sectors to the higher wage sector. However, it takes time to move (e.g., workers need to be re-trained). How fast they can move depends on their training costs, which we assume to be dependent on their education level. Workers that had more years of schooling are presumably better equipped to learn new skills. We do not model schooling decisions here. We simply try to capture workers' heterogeneity by assuming sluggish labor mobility.

Let us assume that time is continuous and that the rate of labor outflow from a low wage sector to the highest wage sector (sector $X$ ) is proportional to the wage differential:

$$
\begin{aligned}
& \frac{d L_{M}(t)}{d t}=\beta L_{M}(t) \times\left[W_{M}(t)-W_{X}(t)\right]<0 \text { for } W_{M}<W_{X} \\
& \frac{d L_{N}(t)}{d t}=-\beta L_{N}(t) \times\left[W_{N}(t)-W_{X}(t)\right]<0 \text { for } W_{N}<W_{X}
\end{aligned}
$$

where $\beta>0$ is the speed of adjustment, which is a function of the average education level of the workforce.

Now, since the wage in each sector equals the value of the marginal product of labour in that sector, we have

$$
\begin{gathered}
W_{X}(t)=p^{*} f^{\prime}\left(L_{X}(t)\right) \\
W_{M}(t)=q^{*} g^{\prime}\left(L_{M}(t)\right) \\
W_{N}(t)=1
\end{gathered}
$$


Let us consider the differential equations

$$
\begin{gathered}
\frac{d L_{N}(t)}{d t}=\beta L_{N}(t)\left[1-p^{*} f^{\prime}\left(L_{X}(t)\right)\right]=\beta\left[\bar{L}-L_{X}(t)-L_{M}(t)\right]\left[1-p^{*} f^{\prime}\left(L_{X}(t)\right)\right] \\
\frac{d L_{M}(t)}{d t}=\beta L_{M}(t)\left[q^{*} g^{\prime}\left(L_{M}(t)\right)-p^{*} f^{\prime}\left(L_{X}(t)\right)\right] .
\end{gathered}
$$

Since $L_{M}+L_{N}+L_{X}=\bar{L}$, we deduce that

$$
\frac{d L_{X}(t)}{d t}=-\frac{d L_{M}(t)}{d t}-\frac{d L_{N}(t)}{d t}
$$

i.e.,

$$
\frac{d L_{X}(t)}{d t}=\beta L_{M}(t)\left[1-q^{*} g^{\prime}\left(L_{M}(t)\right)\right]+\beta\left[\bar{L}-L_{X}(t)\right]\left[p^{*} f^{\prime}\left(L_{X}(t)\right)-1\right] .
$$

Then it can be shown that the system described by the pair of differential equations (2.1) and (2.2) has a steady state that is asymptotically stable. However, in this paper we are interested only in short run questions, for example, what happens to the wage gaps 5 periods after the shock?

\section{An Example}

Assume the demand functions are $D_{X}=A_{X}-p$ and $D_{M}=A_{M}-q$. Assume the production functions are

$$
Q_{X}=f\left(L_{X}\right)=\frac{1}{\alpha}\left(L_{X}\right)^{\alpha} \text { and } Q_{M}=g\left(L_{M}\right)=\frac{1}{\alpha}\left(L_{M}\right)^{\alpha}
$$

Then the condition $p f^{\prime}\left(L_{X}\right)=1$ gives

$$
L_{X}=p^{\frac{1}{1-\alpha}} .
$$

It follows that

$$
\begin{aligned}
& Q_{X}(p)=\frac{1}{\alpha} p^{\frac{\alpha}{1-\alpha}}, \\
& Q_{M}(q)=\frac{1}{\alpha} q^{\frac{\alpha}{1-\alpha}} .
\end{aligned}
$$

The imports demand function is

$$
M(q)=D_{M}(q)-Q_{M}(q)=A_{M}-q-\frac{1}{\alpha} q^{\frac{\alpha}{1-\alpha}} .
$$


and the exports supply function is

$$
X(p)=Q_{X}(p)-D_{X}(p)=\frac{1}{\alpha} p^{\frac{\alpha}{1-\alpha}}-A_{X}+p .
$$

For simplicity, let $\alpha=1 / 2$. Then

$$
\begin{gathered}
M(q)=A_{M}-3 q>0 \text { iff } q<A_{M} / 3 \\
X(p)=3 p-A_{X}>0 \text { iff } p>A_{X} / 3
\end{gathered}
$$

The price elasticity of imports demand is

$$
\mu=-\frac{q M^{\prime}(q)}{M}=\frac{3 q}{A_{M}-3 q}>0 \text { for } M(q)>0
$$

and $\mu>1$ iff $q>A_{M} / 6$. In what follows, we consider $q$ in the range

$$
\frac{A_{M}}{6}<q<\frac{A_{M}}{3}
$$

The price elasticity of export supply is

$$
\varepsilon=\frac{3 p}{3 p-A_{X}}>0 \text { for } X(p)>0
$$

Recall that

$$
\pi=\frac{p}{q}=\frac{P_{X}^{*}}{P_{M}^{*} \tau_{M} \tau_{X}}
$$

The trade balance condition is $M(q)=\pi X(\pi q)$. This yields $A_{M}-3 q=\pi(3 \pi q-$ $\left.A_{X}\right)$, i.e.,

$$
3 q\left(\pi^{2}+1\right)=A_{M}+\pi A_{X} .
$$

Then

$$
q=\frac{A_{M}+\pi A_{X}}{3\left(\pi^{2}+1\right)} .
$$

Note that the restrictions that $q<A_{M} / 3$ and $p>A_{X} / 3$ imply the following restriction on $\pi$

$$
\pi \geq \frac{A_{X} / 3}{q} \geq \frac{A_{X} / 3}{A_{M} / 3}=\frac{A_{X}}{A_{M}} \text { i.e. } \pi A_{M}>A_{X}
$$


From (3.1)

$$
\begin{gathered}
\frac{d q}{d \pi}=\frac{1}{3}\left[\frac{A_{X}\left(\pi^{2}+1\right)-2 \pi\left(A_{M}+\pi A_{X}\right)}{\left(\pi^{2}+1\right)^{2}}\right] \\
=\frac{1}{3}\left[\frac{-A_{X} \pi^{2}+A_{X}-2 \pi A_{M}}{\left(\pi^{2}+1\right)^{2}}\right]<0 \text { because } \pi A_{M}>A_{X}
\end{gathered}
$$

We now assign some numerical values to the parameters $A_{M}, A_{X}$ and $\pi$, and calculate the effect of shock (an increase in $\pi$ ) on the wage gaps, and how the wage gaps are reduced over a number of periods.

\subsection{The initial equilibrium}

Consider an initial situation where

$$
A_{M}=2, A_{X}=1 \text { and } \pi=\pi^{r}=1
$$

(where the superscript $r$ indicate that this is the reference scenario). Then the initial equilibrium prices are

$$
q^{r}=\frac{A_{M}+\pi A_{X}}{3\left(\pi^{2}+1\right)}=\frac{3}{6}=\frac{1}{2}
$$

and

$$
p^{r}=\pi q=\frac{1}{2}
$$

Then

$$
\begin{gathered}
L_{X}^{r}=p^{\frac{1}{1-\alpha}}=\left(\frac{1}{2}\right)^{2}=\frac{1}{4}, Q_{X}^{r}=2 p^{r}=1 \\
L_{M}^{r}=q^{\frac{1}{1-\alpha}}=\frac{1}{4}, Q_{M}^{r}=2 q^{r}=1
\end{gathered}
$$

The value of national income is

$$
\begin{aligned}
Y & =\bar{L}+\left[p Q_{X}^{r}-L_{X}^{r}\right]+\left[q Q_{M}^{r}-L_{M}^{r}\right] \\
& =\bar{L}+\frac{1}{2}
\end{aligned}
$$

Domestic consumption of the goods are

$$
C_{X}^{r}=A_{X}-p=1-\frac{1}{2}=\frac{1}{2}
$$




$$
C_{M}^{r}=A_{M}-p=2-\frac{1}{2}=\frac{3}{2}
$$

Imports are

$$
M(q)=\frac{3}{2}-1=\frac{1}{2}
$$

Exports are

$$
X(q)=3 p-A_{X}=\frac{1}{2}
$$

Domestic consumers' total expenditure on the tradable goods are

$$
p C_{X}+q C_{M}=\left(\frac{1}{2}\right)\left(\frac{1}{2}\right)+\left(\frac{1}{2}\right)\left(\frac{3}{2}\right)=1
$$

Assume that

$$
\bar{L}=1
$$

Then national income is

$$
Y=\bar{L}+\frac{1}{2}=1.5
$$

and thus the consumption of nontraded goods is

$$
C_{N}=Y-\left(p C_{X}+q C_{M}\right)=1.5-1=0.5
$$

The initial labor allocations are $L_{N}=0.5, L_{X}=1 / 4$ and $L_{M}=1 / 4$.

\subsection{A trade shock}

Now, consider an increase in $\pi$ from its initial value of $\pi^{r}=1$, e.g., caused by a fall in $\tau_{X}$. The restriction $\pi>A_{X} / A_{M}$ still holds. Let the new $\pi$ be denoted by $\pi^{*}$. Assume $\pi^{*}=1.2$, i.e., the terms of trade increase by $20 \%$. Then

$$
q^{*}=\frac{A_{M}+\pi^{*} A_{X}}{3\left(\pi^{* 2}+1\right)}=\frac{2+1.2}{3\left((1.2)^{2}+1\right)}=0.43716
$$

and

$$
p^{*}=\pi^{*} q^{*}=0.52459
$$

The new long-run equilibrium allocation of labour is given by

$$
L_{X}^{*}=p^{* \frac{1}{1-\alpha}}=(0.52459)^{2}=0.27519
$$




$$
L_{M}^{*}=\left(q^{*}\right)^{2}=(0.43716)^{2}=0.19111
$$

and

$$
L_{N}^{*}=\bar{L}-L_{X}^{*}-L_{M}^{*}=1-0.27519-0.19111=0.5337
$$

And the long-run equilibrium wages are

$$
\begin{gathered}
W_{X}^{*}=p^{*} f^{\prime}\left(L_{X}^{*}\right)=(0.52459) \frac{1}{\sqrt{0.27519}}=1 \\
W_{M}^{*}=q^{*} g^{\prime}\left(L_{M}^{*}\right)=(0.43716) \frac{1}{\sqrt{0.19111}}=1 \\
W_{N}^{*}=P_{N}^{*}=1,
\end{gathered}
$$

\subsection{Short-run adjustments}

In the short run, labor mobility across sectors is restricted. Immediately after the shock, labor allocation is still the same as at the initial equilibrium. Wages in the three sectors are equal to the value of the marginal product of labor:

$$
\begin{gathered}
W_{X}(t)=p^{*} f^{\prime}\left(L_{X}(t)\right)=p^{*} L_{X}(t)^{\alpha-1}=p^{*} L_{X}(t)^{-1 / 2} \\
W_{M}(t)=q^{*} g^{\prime}\left(L_{M}(t)\right)=q^{*} L_{M}(t)^{-1 / 2} \\
W_{N}(t)=1
\end{gathered}
$$

Then, using eqs (2.1) and (2.2),

$$
\begin{gathered}
\frac{d L_{M}(t)}{d t}=\beta L_{M}(t)\left[q^{*} g^{\prime}\left(L_{M}(t)\right)-p^{*} f^{\prime}\left(L_{X}(t)\right)\right] \\
\frac{d L_{X}(t)}{d t}=\beta L_{M}(t)\left[1-q^{-} g^{\prime}\left(L_{M}(t)\right)\right]+\beta\left[\bar{L}-L_{X}(t)\right]\left[p^{+} f^{\prime}\left(L_{X}(t)\right)-1\right] \\
\dot{L}_{M}=\beta L_{M}\left[q^{*} L_{M}^{-1 / 2}-p^{*} L_{X}^{-1 / 2}\right] \\
\dot{L}_{X}=\beta L_{M}\left[1-q^{*} L_{M}^{-1 / 2}\right]+\beta\left(\bar{L}-L_{X}\right)\left(p^{*} L_{X}^{-1 / 2}-1\right)
\end{gathered}
$$

Discrete-time approximation yields two difference equations:

$$
\begin{gathered}
L_{M}(t+1)=L_{M}(t)+\beta q^{*} L_{M}(t)^{1 / 2}-\beta p^{*} L_{M}(t) L_{X}(t)^{-1 / 2} \\
L_{X}(t+1)=L_{X}(t)+\beta L_{M}(t)-\beta q^{*} L_{M}(t)^{1 / 2}+\beta \bar{L} p^{*} L_{X}^{-1 / 2}-\beta \bar{L}-\beta p^{*} L_{X}^{1 / 2}+\beta L_{X}
\end{gathered}
$$


With $L_{M}(0)=0.25=L_{X}(0), \bar{L}=1$, and $p^{*}=0.52459, q^{*}=0.43716$.

Immediately after the shock, the labor allocation remains unchanged, and thus there is a big divergence in the wage rates. Denote by $W_{X}(0)$ and $W_{M}(0)$ the wage rates in industry $X$ and industry $M$ immediately after the shock:

$$
\begin{gathered}
W_{X}(0)=p^{*} f^{\prime}\left(L_{X}^{r}\right)=0.52459 \times \frac{1}{\sqrt{0.25}}=1.0492 \\
W_{M}(0)=q^{*} g^{\prime}\left(L_{M}^{r}\right)=0.43716 \times \frac{1}{\sqrt{0.25}}=0.87432
\end{gathered}
$$

The wage gap on impact is

$$
G(0) \equiv W_{X}(0)-W_{M}(0)=1.0492-0.87432=0.17488
$$

The average wage is

$$
W_{X} \frac{L_{X}}{\bar{L}}+W_{M} \frac{L_{M}}{\bar{L}}+W_{N} \frac{L_{N}}{\bar{L}}=\frac{1.0492}{4}+\frac{0.87432}{4}+\frac{1}{2}=0.98088
$$

Immediately after the initial shock, the ratio of the average wage of the top $20 \%$ wage earners to that of the bottom $20 \%$ wage earners is

$$
\rho\left(0^{+}\right)=\frac{1.0492}{0.87432}=1.2
$$

Assume that $\beta=0.05$. Using the difference equations (3.3) and (3.4), we compute the employment levels in industries $X$ and $M$ for five periods after the trade shock.

Note that $\beta q^{*}=(0.05) 0.43716=0.021858$ and $\beta p^{*}=(0.05) 0.52459=$ 0.02623 .

PERIOD 1:

$$
L_{M}(1)=0.25+0.021858 \sqrt{0.25}-0.02623\left(\frac{0.25}{\sqrt{0.25}}\right)=0.24781
$$

i.e., a small outflow from sector $M$. The sector-M outflow rate in period 1 is

$$
\frac{0.25-0.24781}{0.25}=0.00876, \text { i.e., less than } 1 \%
$$

$L_{X}(1)=0.25-(0.05)(1-0.25-0.25)-0.021858 \sqrt{0.25}+0.02623 \frac{1}{\sqrt{0.25}}-0.02623 \sqrt{0.25}=0.25342$ 
The sector- $\mathrm{X}$ inflow rate in period 1 is

$$
\frac{0.25342-0.25}{0.25}=0.01368 \text {, i.e., about } 1.4 \%
$$

\section{PERIOD 2:}

$$
L_{M}(2)=0.24781+0.021858 \sqrt{0.24781}-0.02623 \frac{(0.24781)}{\sqrt{0.25342}}=0.24578
$$

$$
L_{X}(2)=0.2565
$$

PERIOD 3:

$$
\begin{gathered}
L_{M}(3)=0.24578+0.021858 \sqrt{0.24578}-0.02623 \frac{(0.24578)}{\sqrt{0.2565}}=0.24389 \\
L_{X}(3)=0.25928
\end{gathered}
$$

PERIOD 4:

$$
\begin{gathered}
L_{M}(4)=0.24389+0.021858 \sqrt{0.24389}-0.02623 \frac{(0.24389)}{\sqrt{0.25928}}=0.24212 \\
L_{X}(4)=0.2618
\end{gathered}
$$

PERIOD 5 :

$$
\begin{gathered}
L_{M}(5)=0.24212+0.021858 \sqrt{0.24212}-0.02623 \frac{(0.24212)}{\sqrt{0.2618}}=0.24046 \\
L_{X}(5)=0.26408
\end{gathered}
$$

So, after 5 periods, the wages are

$$
W_{M}(5)=q^{*} g^{\prime}\left(L_{M}(5)\right)=\frac{0.43716}{\sqrt{0.24046}}=0.89150
$$

and

$$
W_{X}(5)=p^{*} f^{\prime}\left(L_{X}(5)\right)=\frac{0.52459}{\sqrt{0.26408}}=1.0208
$$

The wage gap after 5 periods is

$$
G(5) \equiv W_{X}(5)-W_{M}(5)=1.0208-0.89150=0.1293
$$


The ratio of the average wage of the top $20 \%$ wage earners to that of the bottom $20 \%$ wage earners is (after 5 periods of adjustments) is

$$
\rho(5)=\frac{1.0208}{0.89150}=1.145
$$

This is to be compared with the initial impact effect,

$$
\rho\left(0^{+}\right)=1.2
$$

Thus labour partial mobility leads in a small mitigation of the wage gap after 5 periods. The 5-period mitigation factor, defined as the percentage reduction in the wage gap, is

$$
\frac{G\left(0^{+}\right)-G(5)}{G\left(0^{+}\right)}=\frac{0.17488-0.1293}{0.17488}=0.26064
$$

\subsection{What happens if labor mobility is higher?}

Now, consider a higher coefficient of labor mobility, say $\beta=0.1$. Then

$$
\begin{aligned}
& \beta q^{*}=(0.1) 0.43716=0.043716 \\
& \beta p^{*}=(0.1) 0.52459=0.052459
\end{aligned}
$$

PERIOD 1:

$$
\begin{gathered}
L_{M}(1)=0.25+0.043716 \sqrt{0.25}-0.052459 \frac{(0.25)}{\sqrt{0.25}}=0.24563 \\
L_{X}(1)=0.25683
\end{gathered}
$$

The sector-M outflow rate in period 1 is

$$
\frac{0.25-0.24563}{0.25}=0.01748 \text { i.e., around } 1.7 \%
$$

The sector- $\mathrm{X}$ inflow rate in period 1 is

$$
\frac{0.25683-0.25}{0.25}=0.02732 \text {, i.e., around } 2.7 \%
$$

PERIOD 2:

$$
L_{M}(2)=0.24563+0.043716 \sqrt{0.24563}-0.052459 \frac{(0.24563)}{\sqrt{0.25683}}=0.24187
$$




$$
L_{X}(2)=0.26234
$$

PERIOD 3:

$$
L_{M}(3)=0.24187+0.043716 \sqrt{0.24187}-0.052459 \frac{(0.24187)}{\sqrt{0.26234}}=0.23860
$$

$$
L_{X}(3)=0.26681
$$

PERIOD 4:

$$
L_{M}(4)=0.23860+0.043716 \sqrt{0.23860}-0.052459 \frac{(0.23860)}{\sqrt{0.26681}}=0.23572
$$

$$
L_{X}(4)=0.27046
$$

PERIOD 5:

$$
\begin{gathered}
L_{M}(5)=0.23572+0.043716 \sqrt{0.23572}-0.052459 \frac{(0.23572)}{\sqrt{0.27046}}=0.23317 \\
L_{X}(5)=0.27344
\end{gathered}
$$

Recall $p^{*}=0.52459, q^{*}=0.43716$. The wages in period 5 are

$$
\begin{gathered}
W_{M}(5)=q^{*} g^{\prime}\left(L_{M}(5)\right)=0.90532 \\
W_{X}(5)=\frac{0.52459}{\sqrt{0.27344}}=1.0032
\end{gathered}
$$

The wage gap in period 5 is

$$
1.0032-0.89150=0.1117
$$

As expected, a higher mobility rate implies a mitigation of the wage gap. The 5 -period mitigation factor, defined as the percentage reduction in the wage gap, is

$$
\frac{G\left(0^{+}\right)-G(5)}{G\left(0^{+}\right)}=\frac{0.17488-0.1117}{0.17488}=0.36128
$$

The inequality index in period 5 , defined as the ratio of the income of the top $20 \%$ wage earners to bottom $20 \%$ wage earners, is

$$
\rho(5)=\frac{1.0032}{0.89150}=1.1253
$$

(compared with 1.145 for $\beta=0.05$ ). As expected, the higher labor mobility implies a lower degree of wage inequality. 